\title{
Immiscible silicate liquid partition coefficients: implications for crystal-melt element partitioning and basalt petrogenesis
}

\author{
Ilya V. Veksler · Alexander M. Dorfman • \\ Leonid V. Danyushevsky · Jakob K. Jakobsen · \\ Donald B. Dingwell
}

Received: 20 September 2005/ Accepted: 5 July 2006/Published online: 10 August 2006

(C) Springer-Verlag 2006

\begin{abstract}
This study investigates partitioning of elements between immiscible aluminosilicate and borosilicate liquids using three synthetic mixtures doped with 32 trace elements. In order to get a good spatial separation of immiscible liquids, we employed a hightemperature centrifuge. Experiments were performed at $1,050-1,150^{\circ} \mathrm{C}, 1 \mathrm{~atm}$, in sealed $\mathrm{Fe}$ and Pt containers. Quenched products were analysed by electron microprobe and LA ICP-MS. Nernst partition coefficients ( $D$ 's) between the Fe-rich and Si-rich aluminosilicate immiscible liquids are the highest for $\mathrm{Zn} \mathrm{(3.3)} \mathrm{and} \mathrm{Fe}$ (2.6) and the lowest for $\mathrm{Rb}$ and $\mathrm{K}(0.4-0.5)$. The plots of $D$ values against ionic potential $Z / r$ in all the compositions show a convex upward trend, which is typical also
\end{abstract}

Communicated by J. Hoefs

I. V. Veksler $(\bowtie)$

4.1, GeoForschungsZentrum Potsdam, Telegrafenberg, 14473 Potsdam, Germany

e-mail: veksler@gfz-potsdam.de

A. M. Dorfman

Vernadsky Institute of Geochemistry,

Kosygin Str., 19, 117975 Moscow, Russia

D. B. Dingwell · A. M. Dorfman

Geo \& Umwelt, Universität München,

Theresienstrasse 41, 80333 Munich, Germany

L. V. Danyushevsky

Centre for Ore Deposit Research and School of Earth

Sciences, University of Tasmania, Private Bag 79, Hobart,

TAS 7001, Australia

J. K. Jakobsen

Department of Earth Sciences, University of Aarhus,

C.F. Møllers Allé 110, 8000 Aarhus C, Denmark for element partitioning between immiscible silicate and salt melts. The results bear upon the speciation and structural position of elements in multicomponent silicate liquids. The ferrobasalt-rhyolite liquid immiscibility is observed in evolved basaltic magmas, and may play an important role in large gabbroic intrusions, such as Skaergaard, and during the generation of unusual lavas, such as ferropicrites.

\section{Introduction}

The petrogenetic role of silicate liquid immiscibility has been debated since the start of modern igneous petrology. A popular hypothesis of magma differentiation in early years (Scrope 1825; Daly 1914), immiscibility fell into disrepute for almost half a century in the late 1920s (Greig 1927; Bowen 1928), and the interest in it was revived only in the 1950s and 1970s after the discoveries of low-temperature liquid immiscibility in the system leucite-fayalite-silica (Roedder 1951), and unequivocal evidence of immiscibility in groundmass glasses and melt inclusions of lunar and terrestrial basalts (Philpotts 1976, 1982; Roedder and Weiblen 1970, 1971). At that time, the geologic observations and experimental studies were summarised by Philpotts (1976, 1982) and Roedder (1979), and the main conclusion of petrogenetic relevance was that the most common magmas, such as tholeiitic and alkaline basalts, (and probably also some rhyolites, Naumov et al. 1993), may encounter liquid immiscibility at some, most likely advanced, stage of crystallisation. It seemed that silicate liquid immiscibility was about to regain its status as an important petrogenetic process. However, 
very few studies have further examined the petrogenetic implications. Until now immiscibility remains virtually ignored in models of terrestrial magma evolution. In fact, this process is much more debated for lunar rocks (e.g., Longhi 1990; Shearer et al. 2001) than in the vast literature on terrestrial basalts and granites. In exceptional cases, immiscibility has been involved (but as a side issue) in the debates about magma evolution in the Skaergaard intrusion (McBirney and Nakamura 1974; McBirney and Naslund 1990); it was discussed in connection to the origin of silicic rocks in oceanic crust (Dixon and Rutherford 1979), and in recent years, several studies investigated possible cases of liquid immiscibility in xenoliths and rare types of alkaline plutonic rocks (Hurai et al. 1998; Markl 2001; Rajesh 2003; Sørensen et al. 2003).

Revisiting the chemical aspects of silicate liquid immiscibility is important and timely for several reasons. First, one can now exploit the advantages of modern experimental and analytical tools not available 20 or 30 years ago. For example, the introduction of centrifuge phase separation (Dorfman et al. 1996; Veksler et al. 2002; Schmidt et al. 2006) now enables the collection of small droplets of immiscible liquids into larger, analysable pools, and also distinguishes between stable and metastable immiscibility. The progress in analytical methods, and especially the employment of LA ICP-MS, has improved the detection limits and the precision of trace element analyses. Recent years have also seen a significant progress in theoretical models of silicate liquid immiscibility (e.g., Hudon and Baker 2002a, b; Schmidt et al. 2006, and references therein). Finally, new evidence of immiscible silicate liquids in melt inclusions from classical suites of magmatic rocks, such as the Skaergaard intrusion of layered gabbros, East Greenland (Jakobsen et al. 2005), have shed new light on the extent and petrogenetic importance of liquid immiscibility in tholeiitic and other common magmas. This evidence will hopefully revive the interest of igneous petrologists to the causes and geochemical consequences of silicate liquid immiscibility.

The experimental study presented in this paper aims at examining the regularities of element partitioning between multicomponent immiscible aluminosilicate and borosilicate liquids. The study constitutes a part of our long-term research programme of immiscibility between salt, silicate and aqueous liquids (Veksler et al. 1998, 2002) with implications to natural magmas (Veksler 2004). This paper deals solely with silicate liquid immiscibility, which means that both conjugate liquids are essentially silicate melts, and non-silicate acidic components are either insignificant, or absent.

\section{Experimental and analytical methods}

The establishment of liquid-liquid element partitioning and the determination of precise values of partition coefficients were the main objectives of our study. We wanted to cover several cases of low-temperature silicate liquid immiscibility, with an emphasis on relative variations in partitioning behaviour between the elements, and thus the strategy was to analyse as many elements as possible in products of a single run. Three synthetic starting mixtures were prepared (Table 1): two ferrobasaltic aluminosilicate compositions and a multicomponent borosilicate composition. The ferrobasaltic mixtures SF-1 and SF-2 (Table 1) were based on previously published analyses of synthetic and natural basaltic-rhyolitic immiscible liquid pairs (Longhi 1990; Philpotts 1982; McBirney and Nakamura 1974); the borosilicate composition SB was designed on the basis of phase diagrams of borosilicate ternaries featuring miscibility gaps (Levin et al. 1964), and our previous work on immiscible multicomponent borosilicate mixtures (Veksler et al. 2002).

\section{Preparation of starting mixtures}

The starting mixtures were synthesised by fusion of carefully weighed and mixed reagent-grade chemicals (oxides, carbonates and $\mathrm{H}_{3} \mathrm{BO}_{3}$ ) in $\mathrm{Pt}$ crucibles. In order to avoid strong oxidation and/or Fe losses from the ferrobasaltic mixtures, Fe-free glasses were first prepared by repeated fusions in an electric furnace at 900 and $1,350^{\circ} \mathrm{C}$ and then the glasses were crushed into powder and mixed with reagent-grade $\mathrm{FeO}$ (99.9\%, manufactured by "Aldrich"). Finally, the mixtures

Table 1 Starting mixtures, wt.\% oxides

\begin{tabular}{lrrr}
\hline & SF-1 & SF-2 & SB \\
\hline $\mathrm{SiO}_{2}$ & 56.5 & 54.5 & 40.0 \\
$\mathrm{TiO}_{2}$ & 2.0 & 4.8 & 0.1 \\
$\mathrm{Al}_{2} \mathrm{O}_{3}$ & 6.0 & 7.3 & 2.0 \\
$\mathrm{FeO}$ & 24.0 & 20.0 & 0.1 \\
$\mathrm{MgO}$ & 1.4 & 4.3 & 3.0 \\
$\mathrm{CaO}$ & 6.0 & 7.6 & 3.0 \\
$\mathrm{Na}$ & 0.5 & 1.0 & 1.0 \\
$\mathrm{~K}_{2} \mathrm{O}$ & 2.0 & 1.7 & 1.0 \\
$\mathrm{~B}_{2} \mathrm{O}_{3}$ & 0.0 & 0.0 & 40.0 \\
$\mathrm{SrO}_{\mathrm{BaO}}$ & 0.0 & 0.0 & 3.0 \\
$\mathrm{Rb}_{2} \mathrm{O}$ & 0.0 & 0.0 & 3.0 \\
$\mathrm{Cs}$ & 0.0 & 0.0 & 0.9 \\
$\mathrm{Li}_{2} \mathrm{O}$ & 0.0 & 0.0 & 0.9 \\
$\mathrm{Total}$ & 0.0 & 0.0 & 0.8 \\
& 98.5 & 98.5 & 98.8 \\
\hline
\end{tabular}


were spiked with trace elements $(\mathrm{Li}, \mathrm{Rb}, \mathrm{Cs}, \mathrm{Be}, \mathrm{Sr}, \mathrm{Ba}$, $\mathrm{REE}, \mathrm{Zr}, \mathrm{Hf}, \mathrm{Nb}, \mathrm{Ta}, \mathrm{Zn}, \mathrm{Cu}, \mathrm{Ga}$, In, Sn, Mo, and W), at about 200-300 ppm of each. Most of trace elements were taken for spiking in the form of chemical grade oxides, but hydroxides and concentrated hydroxide solutions were used for $\mathrm{Li}, \mathrm{Rb}$ and $\mathrm{Cs}$, and natural beryl was used as a spike for Be. The oxides were first mixed with each other, and certain amounts of oxide mixtures were then added and thoroughly mixed with the glass-FeO mixtures. Trace element oxide mixtures used for the spiking were not identical for all the starting compositions. Thus, the ferrobasaltic mixtures SF-1 and SF-2 were not spiked with Sn; the borosilicate mixture SB was not spiked with $\mathrm{Cu}$ and Mo. The borosilicate synthetic glass SB contained major amounts of $\mathrm{Li}, \mathrm{Rb}, \mathrm{Cs}, \mathrm{Sr}$ and $\mathrm{Ba}$ (thousands parts per million to weight percents) and was prepared by three subsequent fusions of the reactant mixture of chemicals at 600,950 and $1,300^{\circ} \mathrm{C}$. Before and after the fusions the glassy products were crushed into a fine powder in an agate mortar under acetone.

\section{High-temperature centrifuge runs}

High-temperature centrifuge phase separation has been successfully employed in our previous studies of liquid immiscibility (Veksler et al. 1998; 2002) and the same technique was used in this study. The experimental equipment has been described in detail by Dorfman et al. (1996). Briefly, the runs were performed in a small cylindrical wire-wound electric furnace mounted on a powerful centrifuge, which enabled centrifuge acceleration of up to $1,000 \mathrm{~g}\left(\mathrm{~g}=9.8 \mathrm{~m} / \mathrm{s}^{2}\right)$ and maximal run durations of $3.5 \mathrm{~h}$. In case of highly viscous aluminosilicate and borosilicate liquids, like in this study, phase separation is usually incomplete (Veksler et al. 2002), but the centrifuge technique nevertheless greatly increases the size of the immiscible liquid droplets and thus assists the chemical analyses of run products.

Experimental run conditions are listed in Table 2, and the $\mathrm{Fe}-\mathrm{Pt}$ containers used in the experiments with ferrobasaltic mixtures are presented in Fig. 1. The inner Fe containers shown in Fig. 1 prevented Fe losses into $\mathrm{Pt}$ and served as an oxygen buffer. Experiments with the Fe-free borosilicate mixture SB were performed in single Pt containers of about the same size as those in Fig. 1. About $200 \mathrm{mg}$ of fine-grained powders of the starting mixtures were loaded into the containers, and centrifuged at the conditions listed in Table 2. Unfortunately, the equipment does not allow run durations longer than a few hours. To approach the

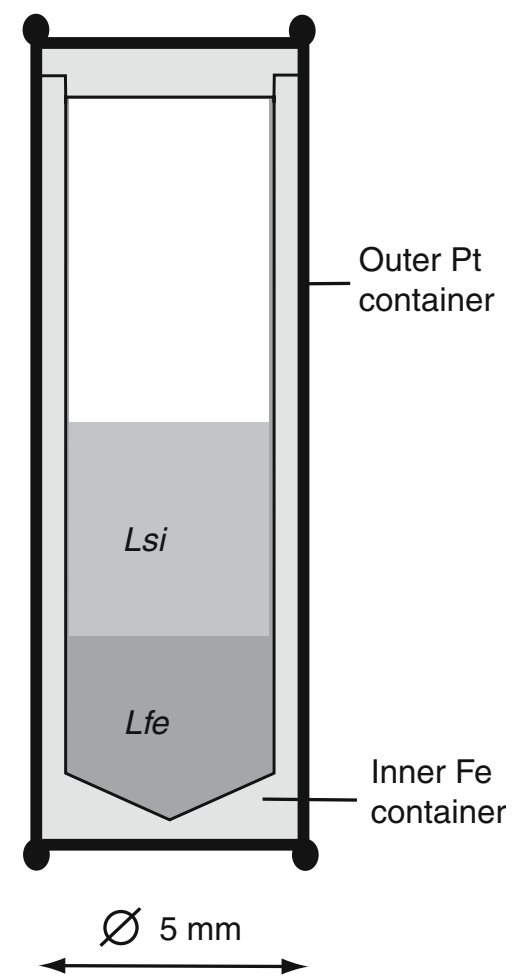

Fig. 1 A sketch of the container used in the experiments with ferrobasaltic compositions. Inner iron container is inside an outer Pt container, which is welded shut. Lsi and $L f e$ are immiscible silica- and Fe-rich liquids

chemical equilibrium as close as possible, experimental charges were first heated without spatial separation of the phases at the minimal rotation rates for about $30 \mathrm{~min}$, and then the phases were separated at the highest rotation rates corresponding to the acceleration of $1,000 \mathrm{~g}$ (Table 2). Quenching was achieved in air by turning the electric furnace off, while the centrifuge rotation continued. Typically 2 min were required to cool the furnace and the charge down to room temperature.

\section{Electron microprobe analyses}

Run products were mounted in epoxy, ground, polished, examined optically in reflected light under microscope, and analysed using Cameca SX-50 electron microprobes (EMP) at the GFZ Potsdam and the Department of Mineralogy, Natural History Museum, London. Analyses were performed in WDS mode at $15 \mathrm{nA}$ beam current and accelerating voltage of $15 \mathrm{kV}$. Counting time for all the other elements was set to $20 \mathrm{~s}$ on peak and $10 \mathrm{~s}$ on background. The following synthetic and natural standards were used for the calibration: orthoclase ( $\mathrm{Al}$ and $\mathrm{K})$, rutile $(\mathrm{Ti})$, wollastonite 
Table 2 Run conditions and phase composition of the products

\begin{tabular}{|c|c|c|c|c|c|c|}
\hline \multirow[t]{2}{*}{ Run no. } & \multirow[t]{2}{*}{ Starting mixture } & \multirow[t]{2}{*}{$t\left({ }^{\circ} \mathrm{C}\right)$} & \multirow[t]{2}{*}{ Duration (h) } & \multicolumn{2}{|c|}{ Acceleration $(g)$} & \multirow[t]{2}{*}{ Phases in run products } \\
\hline & & & & Initial & Final & \\
\hline $\mathrm{C}-36$ & SF-1 & 1,100 & $0.5+2.5^{\mathrm{a}}$ & 160 & 1,000 & $L f e+L s i+\operatorname{tr}+\mathrm{ol}+\mathrm{Fe}-\mathrm{T} i$ \\
\hline $\mathrm{C}-37$ & SF-1 & 1,075 & $0.5+2.5^{\mathrm{a}}$ & 160 & 1,000 & $L f e+L s i+\operatorname{tr}+\mathrm{ol}+\mathrm{Fe}-\mathrm{Ti}$ \\
\hline C-38 & SF-1 & 1,050 & $0.5+2.5^{\mathrm{a}}$ & 160 & 1,000 & $L f e+L s i+\operatorname{tr}+\mathrm{ol}+\mathrm{Fe}-\mathrm{Ti}$ \\
\hline C-39 & SF-1 & 1,125 & $0.5+2.5^{\mathrm{a}}$ & 160 & 1,000 & $L f e+L s i+\operatorname{tr}$ \\
\hline $\mathrm{C}-40$ & SF-1 & 1,150 & $0.5+2.5^{\mathrm{a}}$ & 160 & 1,000 & $L f e+L s i+\operatorname{tr}$ \\
\hline C-137 & SF-2 & 1,160 & $1+2^{\mathrm{a}}$ & 160 & 1,000 & $L f e+L s i+\operatorname{tr}$ \\
\hline $\mathrm{C}-20$ & SB & 1,100 & 1.5 & - & 1,000 & $L f e+L s i$ \\
\hline
\end{tabular}

Abbreviations for phases: $L f e$ ferrobasaltic melt, $L s i$ silicic melt, $L b$ boron-rich melt, $t r$ tridymite, ol olivine, Fe-Ti oxide solid solutions (wüstite and ulvöspinel)

${ }^{a}$ Slow rotation at $160 \mathrm{~g}$ for half an hour followed by fast rotation at $1,000 \mathrm{~g}$ for two and half hours

(Si and $\mathrm{Ca})$, albite and jadeite $(\mathrm{Na})$, diopside and periclase $(\mathrm{Mg})$, celestine $(\mathrm{Sr})$ and barite $(\mathrm{Ba})$. Glasses were analysed with a defocused beam (beam diameter of 5-10 $\mu \mathrm{m}$ ); 5-20 point analyses were performed for each phase to obtain statistically representative averages listed in Tables 2 and 3.

\section{Laser ablation ICP-MS analyses}

Trace element analyses by LA ICP-MS technique were performed using a Hewlett Packard HP4500 ICP-MS in combination with a New Wave UP-213 laser ablation system in the Centre for Ore Deposit Research, University of Tasmania. For this study, analyses were performed in $\mathrm{He}$ atmosphere by ablating $\sim 60-\mu \mathrm{m}$ diameter spots at a rate of 5 shots/s using a laser power of $\sim 12 \mathrm{~J} / \mathrm{cm}^{2}$. The instrument was optimised for sensitivity on mid- to high-mass isotopes (in the range 80240 a.m.u.) and for minimal molecular oxide species (i.e., ${ }^{232} \mathrm{Th}^{16} \mathrm{O} /{ }^{232} \mathrm{Th}<0.3 \%$ ) and doubly charged ion species (i.e., ${ }^{140} \mathrm{Ce}^{2+} /{ }^{140} \mathrm{Ce}^{+}<0.4 \%$ ) production. The low level of molecular oxide and doubly charged ion production precludes the need to correct any of the analyte signal intensities for interfering species. Each analysis was performed in the time-resolved mode which involves sequential peak hopping through the mass spectrum, with the accumulation of 130 measurements of $\sim 20 \mathrm{~ms}$ duration (2.6 s total) for each of the 31 analyte isotopes. The analysis time for each sample was $90 \mathrm{~s}$, comprising a 30-s measurement of background (laser off) and a $60 \mathrm{~s}$ analysis with laseron. Instrument calibration was performed by ablating the NIST612 glass standard (Pearce et al. 1997). Data reduction was undertaken according to standard methods (Longerich et al. 1996) using the NIST612 glass as a primary reference material and $\mathrm{Ca}$ as the internal standard. All analyses were normalised to the USGS BCR-2g glass, which was used as a secondary reference material throughout the analytical sessions. For further control, $\mathrm{Ti}, \mathrm{Fe}$ and $\mathrm{Mg}$ in ferrobasaltic samples, and $\mathrm{Si}$ and $\mathrm{Mg}$ in borosilicate glasses were analysed by both LA ICP-MS and electron microprobe, and the agreement between the two methods was better than $\pm 10 \%$ of measured values for all the samples.

Table 3 Electron microprobe analyses of crystal phases in wt.\% oxides

\begin{tabular}{|c|c|c|c|c|c|c|c|c|c|}
\hline \multirow[t]{2}{*}{ Sample phase } & \multicolumn{3}{|l|}{ C-36 } & \multicolumn{3}{|l|}{ C-37 } & \multicolumn{3}{|l|}{ C-38 } \\
\hline & ol & wu & usp & ol & wu & usp & ol & wu & usp \\
\hline $\mathrm{SiO}_{2}$ & 31.02 & 0.46 & 0.11 & 31.19 & 0.42 & 0.12 & 30.69 & 0.36 & 0.05 \\
\hline $\mathrm{TiO}_{2}$ & 0.19 & 4.52 & 25.54 & 0.28 & 2.95 & 22.18 & 0.27 & 2.57 & 23.26 \\
\hline $\mathrm{Al}_{2} \mathrm{O}_{3}$ & 0.02 & 0.78 & 4.79 & 0.05 & 0.57 & 4.08 & 0.03 & 0.50 & 4.55 \\
\hline $\mathrm{MgO}$ & 5.40 & 0.70 & 0.70 & 5.57 & 0.68 & 0.61 & 4.88 & 0.62 & 0.58 \\
\hline $\mathrm{FeO}$ & 62.47 & 91.04 & 65.89 & 62.11 & 93.90 & 69.45 & 62.64 & 93.64 & 67.73 \\
\hline $\mathrm{CaO}$ & 0.65 & 0.05 & 0.07 & 0.82 & 0.05 & 0.08 & 0.86 & 0.04 & 0.09 \\
\hline $\mathrm{Na}_{2} \mathrm{O}$ & 0.01 & 0.01 & 0.01 & 0.01 & 0.01 & 0.02 & 0.01 & 0.01 & 0.00 \\
\hline $\mathrm{K}_{2} \mathrm{O}$ & 0.02 & 0.03 & 0.01 & 0.03 & 0.01 & 0.02 & 0.03 & 0.02 & 0.00 \\
\hline Total & 99.77 & 97.59 & 97.12 & 100.05 & 98.59 & 96.55 & 99.40 & 97.76 & 96.26 \\
\hline
\end{tabular}

Abbreviations for phases: $o l$ olivine, $w u$ wüstite, $u s p$ ulvöspinel 


\section{Results}

Phase composition and textures of run products

All the experimental samples listed in Table 2 contain two distinct immiscible silicate liquids quenched to glasses, and in most cases also crystalline liquidus phases. Experiments with the ferrobasaltic starting compositions SF-1 and SF-2 produced a dense Fe-rich liquid $L f e$, a light silica-rich liquid $L s i$, fayalitic olivine (Table 3), tridymite and Fe-Ti oxides. The borosilicate composition produced a lighter silica-rich liquid $L s i$, denser B-rich liquid $L b$ and no crystal phases.

Typical textures of run products of the ferrobasaltic compositions are shown in Fig. 2. As evident from the textures, run durations were insufficient for complete spatial separation of the immiscible liquid phases. The starting composition SF-1 produced approximately equal volumes of the immiscible liquids, but because of the high viscosity of Lsi numerous irregular droplets of $L f e$ remained trapped within the $L s i$ layer after $3 \mathrm{~h}$ of centrifuge separation (Fig. 2a). The second starting composition SF-2 produced very little $L s i$, no more than 5-10 vol.\%, and after the separation, the silica-rich liquid Lsi accumulated at the very top of the sample forming relatively large, homogenous droplets enclosing tridymite crystals, but also diffuse streaks resembling plumes of smoke in air or flows of a dye in water (Fig. 2b). The interfaces between the $L f e$ and $L s i$ phases of the ferrobasaltic samples appear blurred and never as sharp as liquid-liquid interfaces in borosilicate samples. In all the samples one could nevertheless find areas of homogenous conjugate glasses large enough for electron microprobe and LA ICP-MS analyses. The bottom layer of the $L f e$ quenched to brownish glass, which looked homogenous (although somewhat turbid) optically, and in backscattered electron (BSE) images. Detailed microprobe analyses of the $L f e$ layers revealed however significant vertical gradients in some samples. The strongest variations were observed for $\mathrm{SiO}_{2}$ and $\mathrm{FeO}$, which showed complimentary trends with silica content increasing, and $\mathrm{FeO}$ concentration decreasing towards the top of the $L f e$ layer (Fig. 3). The gradients might be due to incomplete phase separation of sub-micron liquid emulsions and/or diffusion in homogenous liquid phase, but most likely they formed during quench, which was apparently slow enough for the secondary vertical stratification of the low-viscosity $L f e$ before it quenched to glass. Crystals of Fe-Ti oxides (presumably wüstite and ulvöspinel) and olivine sank to the very bottom of the container (Fig. 2c), while
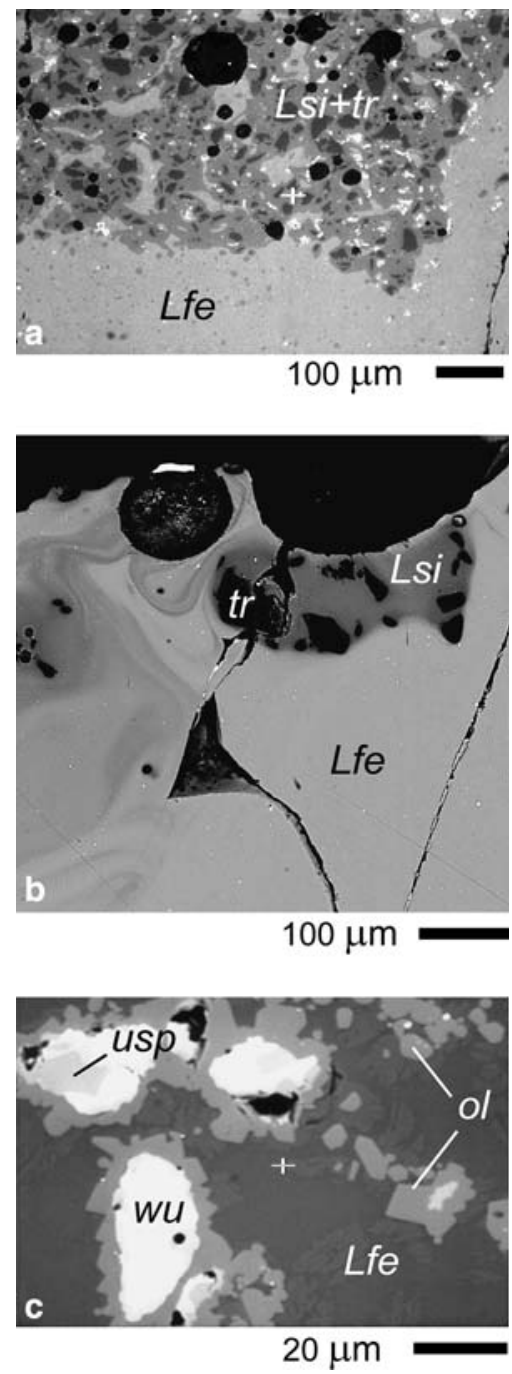

Fig. 2 Backscattered electron images of run products. a Interface between the iron-rich $(L f e)$ and silica-rich $(L s i)$ immiscible liquids in the sample C-38. The upper layer of the silica-rich liquid contains numerous crystals of tridymite (dark grey), and unseparated droplets of the iron-rich liquid (light grey) b Upper part of the sample C-137 with the droplets and plumes of the silica-rich liquid and tridymite crystals $(t r)$. c Olivine and $\mathrm{Fe}-\mathrm{Ti}$ oxide crystals in the iron-rich liquid at the bottom of the sample $\mathrm{C}-38$. White areas of the oxide crystals are wüstite $(w u)$; light grey zones are composed of ulvöspinel ( $u s p)$

tridymite grains all floated up surrounded by $L s i$ (Fig. 2a, b). Olivine typically formed euhedral crystals dispersed in $L f e$, and also corona overgrowths around oxide grains. Tiny spherical metal particles, no more than $1-2 \mu \mathrm{m}$ in size, were found dispersed in the glasses, and larger oval droplets of pure Fe were found in some samples, in contact with wüstite crystals and along the container walls. Some of the metal may have exsolved during quench or resulted from redox reaction between the silicate melts and the $\mathrm{Fe}$ container. 

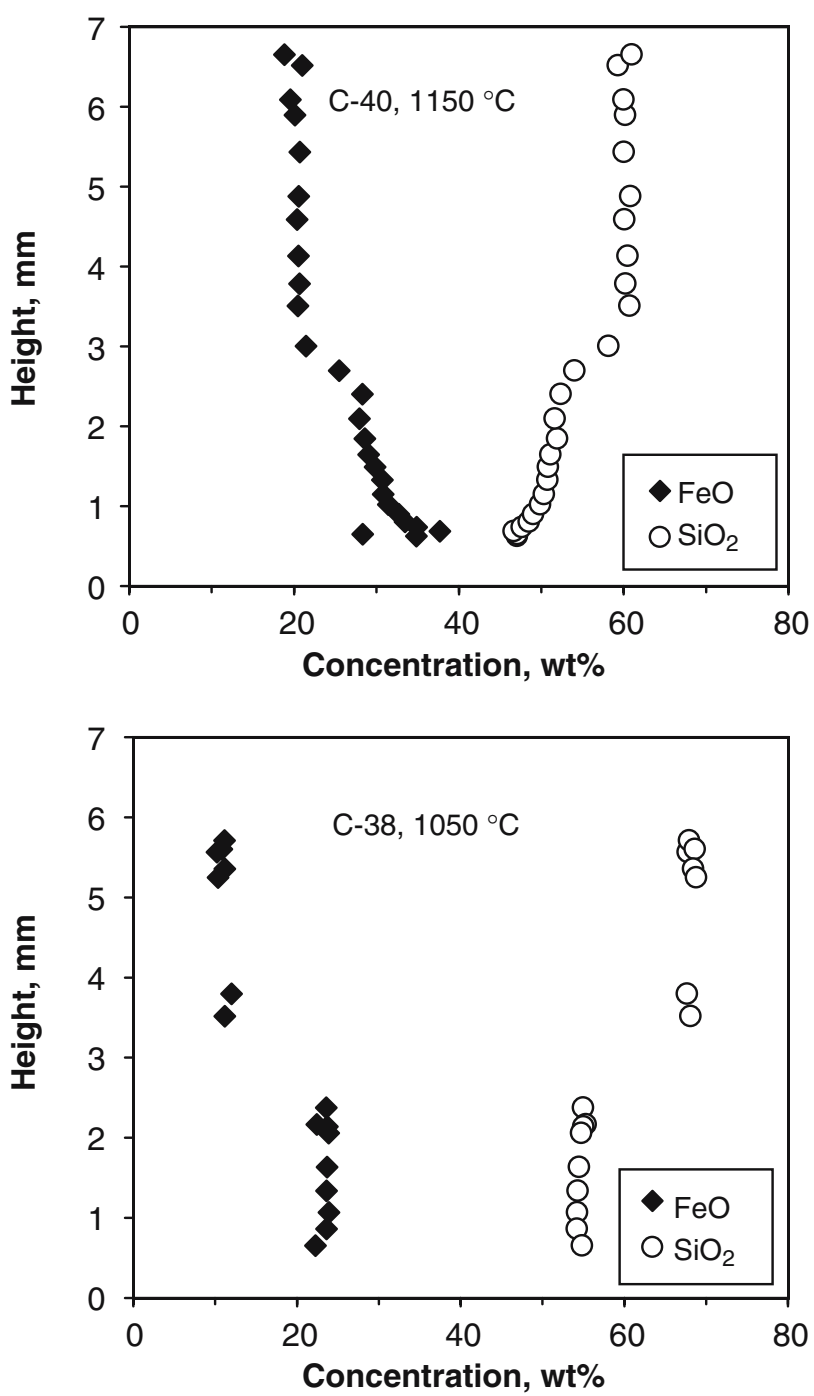

Fig. 3 Vertical compositional gradients of $\mathrm{FeO}$ and $\mathrm{SiO}_{2}$ in quench glasses of the ferrobasaltic samples. See text for discussion

Both immiscible liquids of the borosilicate composition quenched to whitish, semitransparent glasses, similar to those formed in our previous experiments with borosilicate melts (Veksler et al. 2002). Centrifuge separation of the liquids was also incomplete and resulted in three layers of approximately equal height: homogenous $L b$ glass at the bottom, homogenous $L s i$ glass at the top, and a medium layer of intermingling spherical droplets of one immiscible melt in another. Electron microprobe study of the borosilicate sample C-20 did not reveal any significant compositional gradients in the homogenous layers, and the chemical compositions of the $L s i$ and $L b$ glasses were found to be uniform in the layers and dispersed droplets throughout the sample.
Chemical composition of coexisting phases

Crystal phases

All the ferrobasaltic run products contain tridymite, although in the sample C-40 run at $1,150^{\circ} \mathrm{C}$ it is present only in trace amounts, and probably is a quench phase. Olivine and Fe-Ti-oxides crystallised in the SF-1 starting composition below $1,120^{\circ} \mathrm{C}$. Electron microprobe analyses of the crystal phases are presented in Table 3. The analyses of tridymite are not included, but they were found to correspond to pure $\mathrm{SiO}_{2}$. The composition of olivine varies slightly with falling temperature from $\mathrm{Fo}_{14}$ to $\mathrm{Fo}_{12}$, but the variation is about the same as the extent of compositional zoning in a single sample. Oxide crystals are Fe-Ti solid solutions composed of two distinct inter-grown phases. The predominant phase is interpreted as wüstite with $2.5-4.6$ wt. $\% \mathrm{TiO}_{2}$ and less than 1 wt. $\% \mathrm{MgO}$ and $\mathrm{Al}_{2} \mathrm{O}_{3}$. The second, less abundant phase contains more than 22 wt. $\% \mathrm{TiO}_{2}, 4-4.8$ wt. $\% \mathrm{Al}_{2} \mathrm{O}_{3}$, and approaches the composition of ulvöspinel.

\section{Immiscible liquids}

Electron microprobe and LA ICP-MS analyses of the glasses (quenched liquids) are listed in Table 4. The conjugate immiscible liquids of the ferrobasaltic compositions $(L f e)$ are similar to those produced in previous experimental studies (McBirney and Nakamura 1974; Dixon and Rutherford 1979; Longhi 1990) and found in natural volcanic glasses (Roedder and Wieblen 1971; Roedder 1979; Philpotts 1982; Jakobsen et al. 2005). The hallmarks of the $L f e$ are very high contents of iron oxides totalling to $28-35$ wt. $\%$, and high $\mathrm{CaO} /$ $\mathrm{Al}_{2} \mathrm{O}_{3}$ values usually exceeding 1 in mass units. Silica content in the $L f e$ is at about $48-54$ wt.\% in this study, but it can be as low as $38-40 \mathrm{wt}$ \% according to some previously published experimental and natural compositions. The compositions of the conjugate silica-rich liquid $L s i$ are similar to those of natural rhyodacites, with $\mathrm{SiO}_{2}$ around 60-75 wt.\% and high feldspar norms. Thus, in terms of liquid-liquid element partitioning the silica-rich conjugate liquid is enriched in alkalis (except $\mathrm{Li}), \mathrm{Al}$ and $\mathrm{Si}$. All the other elements with a possible exception of Mo concentrate in the $L f e$.

The immiscible silica-rich liquid $L s i$ in the borosilicate composition is composed mostly of $\mathrm{SiO}_{2}$ and $\mathrm{B}_{2} \mathrm{O}_{3}$. The latter was not analysed directly by electron microprobe, but according to the low totals, the combined concentration of both oxides amounts to more than $90 \mathrm{wt} \%$ (Table 3). All the other major oxides are at concentration levels below 2 wt.\%. The conjugate boron-rich 
Table 4 Compositions of immiscible liquids based on electron microprobe and LA ICP-MS analyses of quenched glasses

\begin{tabular}{|c|c|c|c|c|c|c|c|c|c|c|c|c|c|c|}
\hline \multirow{3}{*}{$\begin{array}{l}\text { Sample } \\
T\left({ }^{\circ} \mathrm{C}\right) \\
\text { Phase }\end{array}$} & \multirow{2}{*}{\multicolumn{2}{|c|}{$\frac{C-36}{1,100}$}} & \multirow{2}{*}{\multicolumn{2}{|c|}{$\frac{C-37}{1,075}$}} & \multirow{2}{*}{\multicolumn{2}{|c|}{$\frac{C-38}{1,050}$}} & \multirow{2}{*}{\multicolumn{2}{|c|}{$\frac{C-39}{1,125}$}} & \multirow{2}{*}{\multicolumn{2}{|c|}{$\frac{C-40}{1,150}$}} & \multirow{2}{*}{\multicolumn{2}{|c|}{$\frac{C-137}{1,160}$}} & \multirow{2}{*}{\multicolumn{2}{|c|}{$\frac{\mathrm{C}-20}{1,100}$}} \\
\hline & & & & & & & & & & & & & & \\
\hline & $L s i$ & Lfe & Lsi & Lfe & $L s i$ & $L f e$ & Lsi & $L f e$ & Lsi & Lfe & Lsi & Lfe & Lsi & $L b$ \\
\hline $\mathrm{SiO}_{2}$ & 69.36 & 49.20 & 68.94 & 52.58 & 68.18 & 54.42 & 60.11 & 48.25 & 60.09 & 49.63 & 67.06 & 51.42 & 55.66 & 35.03 \\
\hline $\mathrm{TiO}_{2}$ & 1.33 & 2.34 & 1.37 & 2.22 & 1.49 & 2.50 & 2.18 & 2.18 & 2.14 & 2.27 & 2.46 & 4.84 & 0.08 & 0.14 \\
\hline $\mathrm{Al}_{2} \mathrm{O}_{3}$ & 7.63 & 5.60 & 7.78 & 6.14 & 8.46 & 6.27 & 6.36 & 5.39 & 6.30 & 5.51 & 6.44 & 6.92 & 1.53 & 2.17 \\
\hline $\mathrm{MgO}$ & 0.60 & 1.26 & 0.59 & 1.09 & 0.48 & 0.93 & 1.03 & 1.25 & 1.02 & 1.19 & 1.52 & 2.92 & 1.12 & 2.91 \\
\hline $\mathrm{FeO}$ & 12.03 & 31.13 & 11.86 & 26.64 & 10.98 & 23.58 & 20.43 & 32.65 & 20.38 & 31.33 & 10.81 & 20.94 & 0.007 & 0.015 \\
\hline $\mathrm{CaO}$ & 3.01 & 6.86 & 3.25 & 7.12 & 3.55 & 7.82 & 5.37 & 6.60 & 5.41 & 7.03 & 3.73 & 7.48 & 1.41 & 3.86 \\
\hline $\mathrm{SrO}$ & 0.08 & 0.11 & & & & & 0.11 & 0.12 & & & & & 1.14 & 3.05 \\
\hline $\mathrm{BaO}$ & 0.00 & 0.02 & & & & & 0.01 & 0.02 & & & & & 0.60 & 1.47 \\
\hline $\mathrm{Na}_{2} \mathrm{O}$ & 0.64 & 0.41 & 0.66 & 0.49 & 0.69 & 0.50 & 0.51 & 0.41 & 0.51 & 0.41 & 1.05 & 0.98 & 0.72 & 1.05 \\
\hline $\mathrm{K}_{2} \mathrm{O}$ & 4.59 & 1.95 & 4.75 & 2.45 & 4.93 & 2.48 & 3.17 & 1.87 & 2.84 & 1.79 & 4.15 & 2.34 & 0.83 & 1.04 \\
\hline $\mathrm{Rb}_{2} \mathrm{O}$ & 0.20 & 0.10 & 0.18 & 0.12 & 0.18 & 0.11 & 0.14 & 0.09 & & & & & 0.98 & 1.15 \\
\hline $\mathrm{Cs}_{2} \mathrm{O}$ & & & & & & & & & & & & & 1.02 & 1.07 \\
\hline Total & 99.47 & 98.97 & 99.39 & 98.84 & 98.94 & 98.61 & 99.42 & 98.81 & 98.70 & 99.14 & 97.21 & 97.84 & 65.09 & 52.95 \\
\hline $\mathrm{Li}$ & 188 & 345 & & & 260 & 399 & 333 & 333 & 337 & 358 & 167 & 180 & 1,523 & 3,012 \\
\hline $\mathrm{Be}$ & 63 & 119 & & & 74 & 129 & 105 & 107 & 116 & 125 & 68 & 96 & 37 & 75 \\
\hline $\mathrm{Cu}$ & 66 & 147 & & & 67 & 112 & 81 & 96 & 104 & 121 & 26 & 56 & 5.5 & 4.8 \\
\hline $\mathrm{Zn}$ & 105 & 378 & & & 193 & 428 & 321 & 372 & 147 & 366 & 51 & 141 & 3.5 & 3.0 \\
\hline $\mathrm{Ga}$ & 153 & 266 & & & 227 & 296 & 260 & 254 & 215 & 233 & 151 & 213 & 7.8 & 16.6 \\
\hline $\mathrm{Rb}$ & 471 & 480 & & & 852 & 643 & 847 & 505 & 806 & 574 & 690 & 498 & 5,333 & 6,041 \\
\hline $\mathrm{Sr}$ & 659 & 1,439 & & & 811 & 1,603 & 1,191 & 1,353 & 1,205 & 1,422 & 538 & 1,158 & 6,376 & 17,898 \\
\hline$Y$ & 70 & 143 & & & 79 & 170 & 128 & 135 & 128 & 142 & 65 & 133 & 77 & 213 \\
\hline $\mathrm{Zr}$ & 228 & 379 & & & 275 & 455 & 412 & 370 & 406 & 395 & 237 & 384 & 280 & 523 \\
\hline $\mathrm{Nb}$ & 191 & 366 & & & 209 & 411 & 338 & 338 & 342 & 366 & 174 & 390 & 258 & 534 \\
\hline Mo & 87 & 169 & & & 199 & 162 & 173 & 93 & 158 & 160 & 101 & 96 & 4.4 & 3.8 \\
\hline In & 179 & 442 & & & 283 & 517 & 467 & 450 & 272 & 469 & & & d. 1. & d. 1. \\
\hline Sn & 4.1 & 7.6 & & & 5.1 & 8.3 & 8.1 & 8.5 & & & & & 187 & 386 \\
\hline Cs & & & & & & & & & & & 689 & 477 & & \\
\hline $\mathrm{Ba}$ & 696 & 1,371 & & & 945 & 1,594 & 1,263 & 1,317 & 1,258 & 1,376 & 572 & 1,07 & 4,749 & 12,306 \\
\hline $\mathrm{La}$ & 71 & 151 & & & 81 & 179 & 131 & 143 & 131 & 149 & 57 & 141 & 77 & 224 \\
\hline $\mathrm{Ce}$ & 63 & 134 & & & 70 & 156 & 114 & 125 & 116 & 133 & 40 & 104 & 68 & 191 \\
\hline $\operatorname{Pr}$ & 70 & 150 & & & 79 & 176 & 128 & 141 & 127 & 146 & 50 & 128 & 73 & 213 \\
\hline $\mathrm{Nd}$ & 72 & 154 & & & 81 & 182 & 132 & 146 & 130 & 149 & 57 & 143 & 77 & 222 \\
\hline $\mathrm{Sm}$ & 73 & 155 & & & 84 & 187 & 136 & 149 & 133 & 153 & 57 & 146 & 80 & 229 \\
\hline $\mathrm{Eu}$ & 71 & 162 & & & 84 & 181 & 130 & 152 & 135 & 165 & 56 & 141 & 81 & 230 \\
\hline $\mathrm{Gd}$ & 75 & 157 & & & 83 & 183 & 135 & 146 & 133 & 151 & 62 & 149 & 78 & 226 \\
\hline $\mathrm{Tb}$ & 76 & 159 & & & 85 & 184 & 136 & 148 & 139 & 157 & 60 & 143 & 76 & 217 \\
\hline Dy & 75 & 156 & & & 84 & 186 & 136 & 148 & 138 & 156 & 66 & 156 & 83 & 236 \\
\hline Ho & 76 & 158 & & & 85 & 185 & 138 & 148 & 139 & 155 & 67 & 154 & 84 & 236 \\
\hline $\mathrm{Er}$ & 77 & 157 & & & 88 & 191 & 142 & 153 & 140 & 156 & 66 & 154 & 84 & 233 \\
\hline $\mathrm{Tm}$ & 76 & 155 & & & 86 & 185 & 139 & 149 & 137 & 152 & 69 & 154 & 86 & 236 \\
\hline $\mathrm{Yb}$ & 77 & 155 & & & 92 & 194 & 147 & 157 & 145 & 161 & 72 & 165 & 91 & 250 \\
\hline $\mathrm{Lu}$ & 79 & 159 & & & 91 & 192 & 146 & 155 & 143 & 158 & 74 & 160 & 90 & 245 \\
\hline $\mathrm{Hf}$ & 240 & 406 & & & 299 & 468 & 416 & 389 & 426 & 425 & 258 & 420 & 319 & 627 \\
\hline $\mathrm{Ta}$ & 247 & 450 & & & 281 & 503 & 421 & 412 & 451 & 468 & 239 & 481 & 366 & 647 \\
\hline W & 177 & 392 & & & 227 & 446 & 305 & 367 & 290 & 373 & 94 & 200 & 241 & 642 \\
\hline $\mathrm{Pb}$ & & & & & & & & & & & 1.6 & 4.5 & & \\
\hline Th & 0.12 & 0.22 & & & 0.14 & 0.25 & 0.22 & 0.20 & 0.23 & 0.20 & 0.13 & 0.25 & 0.06 & 0.14 \\
\hline $\mathrm{U}$ & 0.08 & 0.14 & & & 0.09 & 0.19 & 0.14 & 0.14 & 0.15 & 0.14 & 0.06 & 0.00 & 0.03 & 0.08 \\
\hline
\end{tabular}

Oxide concentrations are in wt. \%, trace elements, in ppm

liquid $L b$ is also enriched in network-modifying elements and low in $\mathrm{SiO}_{2}$ (35 wt.\%). The compositional features of the immiscible borosilicate liquids are in good agreement with the immiscibility patterns in borosilicate ternaries (Levin et al. 1964) and our previous study of multicomponent systems (Veksler et al. 2002).

\section{Liquid-liquid partition coefficients}

The simplest conventional way to quantify element partitioning is by Nernst partition coefficients $D$ 's, calculated as oxide or elemental ratios: 
$D_{i}=\frac{C_{i}^{\mathrm{Lfe}}}{C_{i}^{\mathrm{Lsi}}}$

where $C$ 's are weight concentrations, subscripts denote components, and superscripts denote phases ( $L f e, \mathrm{Fe}-$ rich melt; $L s i$, silica-rich melt). In case of the borosilicate conjugate liquids, weight concentrations in $L b$ are divided by the concentrations in the conjugate Lsi. The liquid-liquid $D$ values calculated from the concentrations in Table 4 are presented in Table 5. Elements are grouped according to their ionic charge $Z$, and for each ion the table also lists coordination number $\mathrm{CN}$, ionic radius $r$, and ionic potential $Z / r$. Some elements having multiple oxidation states ( $\mathrm{Sn}$, Mo and $\mathrm{W}$ ) are presented by two alternative cations (see discussion below). The coordination numbers are mostly based on

Table 5 Ionic properties and liquid-liquid $D$ values

\begin{tabular}{|c|c|c|c|c|c|c|c|c|c|c|c|}
\hline & \multirow[t]{2}{*}{$Z$} & \multirow[t]{2}{*}{$N$} & \multirow[t]{2}{*}{$r(\mathrm{pm})$} & \multirow[t]{2}{*}{$Z / r\left(\times 10^{3}\right)$} & \multicolumn{7}{|c|}{ Nernst partition coefficients $(D)$} \\
\hline & & & & & C-36 & C-37 & C-38 & C-39 & $\mathrm{C}-40$ & C-137 & $\mathrm{C}-20$ \\
\hline Cs & $1+$ & 8 & 188 & 5.3 & & & & & & $0.69(0.21)$ & $1.05(0.08)$ \\
\hline $\mathrm{Rb}$ & $1+$ & 6 & 166 & 6.0 & $0.48(0.15)$ & & $0.59(0.11)$ & $0.60(0.05)$ & $0.71(0.03)$ & $0.72(0.13)$ & $1.17(0.04)$ \\
\hline K & $1+$ & 6 & 152 & 6.6 & $0.42(0.03)$ & $0.52(0.08)$ & $0.50(0.04)$ & $0.59(0.06)$ & $0.63(0.12)$ & $0.56(0.03)$ & $1.25(0.06)$ \\
\hline $\mathrm{Na}$ & $1+$ & 6 & 116 & 8.6 & $0.64(0.12)$ & $0.74(0.09)$ & $0.72(0.07)$ & $0.80(0.10)$ & $0.80(0.15)$ & $0.94(0.08)$ & $1.45(0.09)$ \\
\hline $\mathrm{Li}$ & $1+$ & 5 & 82 & 12.2 & $1.84(0.16)$ & & $1.53(0.18)$ & $1.00(0.05)$ & $1.06(0.04)$ & $1.07(0.12)$ & $1.98(0.10)$ \\
\hline $\mathrm{Cu}$ & $1+$ & 6 & 91 & 11.0 & $2.22(0.13)$ & & $1.67(0.36)$ & $1.18(0.05)$ & $1.16(0.08)$ & $2.13(0.13)$ & $0.88(0.23)$ \\
\hline $\mathrm{Ba}$ & $2+$ & 6 & 149 & 13.4 & $1.97(0.10)$ & & $1.69(0.11)$ & $1.04(0.03)$ & $1.09(0.02)$ & $1.93(0.10)$ & $2.45(0.16)$ \\
\hline $\mathrm{Sr}$ & $2+$ & 6 & 132 & 15.2 & $2.18(0.07)$ & & $1.98(0.07)$ & $1.14(0.01)$ & $1.18(0.03)$ & $2.15(0.08)$ & $2.68(0.08)$ \\
\hline $\mathrm{Ca}$ & $2+$ & 6 & 114 & 17.5 & $2.28(0.26)$ & $2.19(0.46)$ & $2.21(0.17)$ & $1.23(0.03)$ & $1.30(0.28)$ & $2.41(0.12)$ & $2.74(0.10)$ \\
\hline $\mathrm{Mg}$ & $2+$ & 6 & 86 & 23.3 & $2.10(0.25)$ & $1.85(0.38)$ & $1.93(0.41)$ & $1.21(0.10)$ & $1.16(0.16)$ & $1.92(0.15)$ & $2.60(0.08)$ \\
\hline $\mathrm{Be}$ & $2+$ & 5 & 50 & 40.0 & $1.89(0.05)$ & & $1.74(0.12)$ & $1.02(0.02)$ & $1.08(0.03)$ & $1.42(0.07)$ & $2.05(0.14)$ \\
\hline $\mathrm{Zn}$ & $2+$ & 6 & 88 & 22.7 & $3.59(0.31)$ & & $2.22(0.90)$ & $1.16(0.04)$ & 2.49 (0.17) & $2.80(0.27)$ & $0.87(0.30)$ \\
\hline $\mathrm{Fe}$ & $2+$ & 6 & 92 & 21.7 & $2.59(0.28)$ & $2.25(0.40)$ & $2.15(0.13)$ & $1.60(0.09)$ & $1.54(0.16)$ & $1.94(0.12)$ & $1.97(0.31)$ \\
\hline Sn & $2+$ & 6 & 123 & 16.3 & $1.86(0.16)$ & & $1.63(0.41)$ & $1.04(0.10)$ & & & \\
\hline $\mathrm{Pb}$ & $2+$ & 6 & 133 & 15.0 & & & & & & $2.77(0.32)$ & \\
\hline $\mathrm{Eu}$ & $2+$ & 6 & 131 & 15.3 & $2.29(0.08)$ & & $2.15(0.05)$ & $1.17(0.02)$ & $1.22(0.04)$ & $2.49(0.13)$ & \\
\hline Y & $3+$ & 7 & 110 & 27.3 & $2.03(0.05)$ & & $2.16(0.09)$ & $1.06(0.02)$ & $1.11(0.03)$ & $2.03(0.19)$ & $2.77(0.10)$ \\
\hline $\mathrm{La}$ & $3+$ & 7 & 123 & 24.4 & $2.12(0.06)$ & & $2.22(0.11)$ & $1.09(0.02)$ & $1.14(0.03)$ & $2.50(0.24)$ & $2.91(0.13)$ \\
\hline $\mathrm{Ce}$ & $3+$ & 6 & 115 & 26.1 & $2.13(0.08)$ & & $2.24(0.11)$ & $1.10(0.02)$ & $1.15(0.04)$ & $2.58(0.23)$ & $2.80(0.10)$ \\
\hline $\operatorname{Pr}$ & $3+$ & 6 & 113 & 26.5 & $2.14(0.07)$ & & $2.23(0.10)$ & $1.10(0.02)$ & $1.15(0.03)$ & $2.56(0.22)$ & $2.92(0.14)$ \\
\hline $\mathrm{Nd}$ & $3+$ & 6 & 112.3 & 26.7 & $2.14(0.08)$ & & $2.24(0.09)$ & $1.10(0.02)$ & $1.15(0.03)$ & $2.51(0.24)$ & $2.88(0.09)$ \\
\hline $\mathrm{Sm}$ & $3+$ & 6 & 109.8 & 27.3 & $2.13(0.07)$ & & $2.23(0.10)$ & $1.10(0.02)$ & $1.14(0.03)$ & $2.55(0.24)$ & $2.88(0.11)$ \\
\hline $\mathrm{Eu}$ & $3+$ & 6 & 108.7 & 27.6 & & & & & & & $2.83(0.11)$ \\
\hline Gd & $3+$ & 6 & 107.8 & 27.8 & $2.10(0.07)$ & & $2.21(0.10)$ & $1.09(0.02)$ & $1.13(0.03)$ & $2.38(0.26)$ & $2.89(0.15)$ \\
\hline $\mathrm{Tb}$ & $3+$ & 6 & 106.3 & 28.2 & $2.09(0.07)$ & & $2.18(0.10)$ & $1.09(0.03)$ & $1.13(0.03)$ & $2.38(0.26)$ & $2.86(0.12)$ \\
\hline Dy & $3+$ & 6 & 105.2 & 28.5 & $2.08(0.06)$ & & $2.20(0.10)$ & $1.09(0.03)$ & $1.13(0.03)$ & $2.37(0.24)$ & $2.85(0.13)$ \\
\hline Ho & $3+$ & 6 & 104.1 & 28.8 & $2.07(0.06)$ & & $2.17(0.10)$ & $1.08(0.02)$ & $1.12(0.03)$ & $2.30(0.24)$ & $2.82(0.12)$ \\
\hline $\mathrm{Er}$ & $3+$ & 6 & 103 & 29.1 & $2.05(0.06)$ & & $2.17(0.11)$ & $1.08(0.02)$ & $1.11(0.03)$ & $2.32(0.26)$ & $2.76(0.10)$ \\
\hline $\mathrm{Tm}$ & $3+$ & 6 & 102 & 29.4 & $2.04(0.06)$ & & $2.15(0.10)$ & $1.07(0.02)$ & $1.11(0.02)$ & $2.24(0.21)$ & $2.75(0.10)$ \\
\hline $\mathrm{Yb}$ & $3+$ & 6 & 100.8 & 29.8 & $2.03(0.05)$ & & $2.12(0.11)$ & $1.07(0.03)$ & $1.11(0.02)$ & $2.29(0.28)$ & $2.74(0.11)$ \\
\hline $\mathrm{Lu}$ & $3+$ & 6 & 100.1 & 30.0 & $2.02(0.05)$ & & $2.11(0.10)$ & $1.07(0.02)$ & $1.10(0.02)$ & $2.17(0.20)$ & $2.73(0.09)$ \\
\hline $\mathrm{Ga}$ & $3+$ & 6 & 76 & 39.5 & $1.74(0.09)$ & & $1.30(0.21)$ & $0.97(0.06)$ & $1.08(0.03)$ & $1.41(0.10)$ & $2.15(0.25)$ \\
\hline In & $3+$ & 6 & 94 & 31.9 & $2.47(0.23)$ & & $1.83(0.65)$ & $0.96(0.04)$ & $1.73(0.06)$ & & \\
\hline $\mathrm{Al}$ & $3+$ & 4 & 53 & 56.6 & $0.73(0.02)$ & $0.79(0.05)$ & $0.74(0.04)$ & $0.85(0.02)$ & $0.87(0.05)$ & $1.07(0.03)$ & $1.42(0.05)$ \\
\hline Sn & $4+$ & 6 & 83 & 48.2 & & & & & & & $2.06(0.11)$ \\
\hline Th & $4+$ & 8 & 119 & 33.6 & $1.84(0.23)$ & & $1.74(0.59)$ & $0.93(0.14)$ & $0.90(0.06)$ & $1.85(0.17)$ & $2.25(0.45)$ \\
\hline $\mathrm{U}$ & $4+$ & 8 & 114 & 35.1 & $1.73(0.11)$ & & $2.19(0.44)$ & $1.02(0.16)$ & $0.98(0.09)$ & & $2.23(0.68)$ \\
\hline $\mathrm{Zr}$ & $4+$ & 8 & 98 & 40.8 & $1.66(0.06)$ & & $1.66(0.10)$ & $0.90(0.03)$ & $0.97(0.03)$ & $1.62(0.06)$ & $1.87(0.10)$ \\
\hline $\mathrm{Hf}$ & $4+$ & 6 & 85 & 47.1 & $1.69(0.07)$ & & $1.56(0.10)$ & $0.94(0.03)$ & $1.00(0.02)$ & $1.63(0.08)$ & $1.97(0.10)$ \\
\hline $\mathrm{Ti}$ & $4+$ & 5 & 66 & 60.6 & $1.76(0.16)$ & $1.61(0.24)$ & $1.68(0.30)$ & $1.00(0.03)$ & $1.06(0.10)$ & $1.97(0.20)$ & $1.89(0.36)$ \\
\hline $\mathrm{Si}$ & $4+$ & 4 & 40 & 100 & $0.71(0.03)$ & $0.76(0.05)$ & $0.80(0.01)$ & $0.80(0.02)$ & $0.83(0.03)$ & $0.77(0.01)$ & $0.63(0.01)$ \\
\hline Mo & $4+$ & 6 & 79 & 50.6 & $1.94(0.96)$ & & $0.82(0.37)$ & $0.54(0.25)$ & $1.01(0.26)$ & $0.96(0.52)$ & \\
\hline W & $4+$ & 6 & 80 & 50.0 & $2.21(0.12)$ & & $1.97(0.32)$ & $1.20(0.08)$ & $1.29(0.08)$ & $2.12(0.38)$ & \\
\hline $\mathrm{Nb}$ & $5+$ & 6 & 78 & 64.1 & $1.92(0.05)$ & & $1.97(0.13)$ & $1.00(0.03)$ & $1.07(0.02)$ & $2.24(0.18)$ & $2.07(0.09)$ \\
\hline $\mathrm{Ta}$ & $5+$ & 6 & 78 & 64.1 & $1.82(0.05)$ & & $1.79(0.07)$ & $0.98(0.03)$ & $1.04(0.02)$ & $2.01(0.18)$ & $1.77(0.12)$ \\
\hline Мо & $6+$ & 6 & 73 & 82.2 & & & & & & & $0.86(0.29)$ \\
\hline W & $6+$ & 6 & 74 & 81.1 & & & & & & & $2.67(0.08)$ \\
\hline
\end{tabular}

Standard deviations are in brackets 
the spectroscopic evidence reviewed by Hudon and Baker (2002a), and ionic radii are from Shannon (1976), assuming $r \mathrm{O}^{2-}=121 \mathrm{pm}$, and with the highspin value for $\mathrm{Fe}^{2+}$. Standard deviations of the $D$ values are given in brackets in Table 5. They were calculated using error propagation formulae from standard deviations of the average concentrations. In Fig. 4 the liquid-liquid $D$ values of three most representative experimental samples are plotted against $Z / r$. In the series of experiments with the starting composition SF-1 (samples from C-36 to C-40, Table 2), $D$ values in
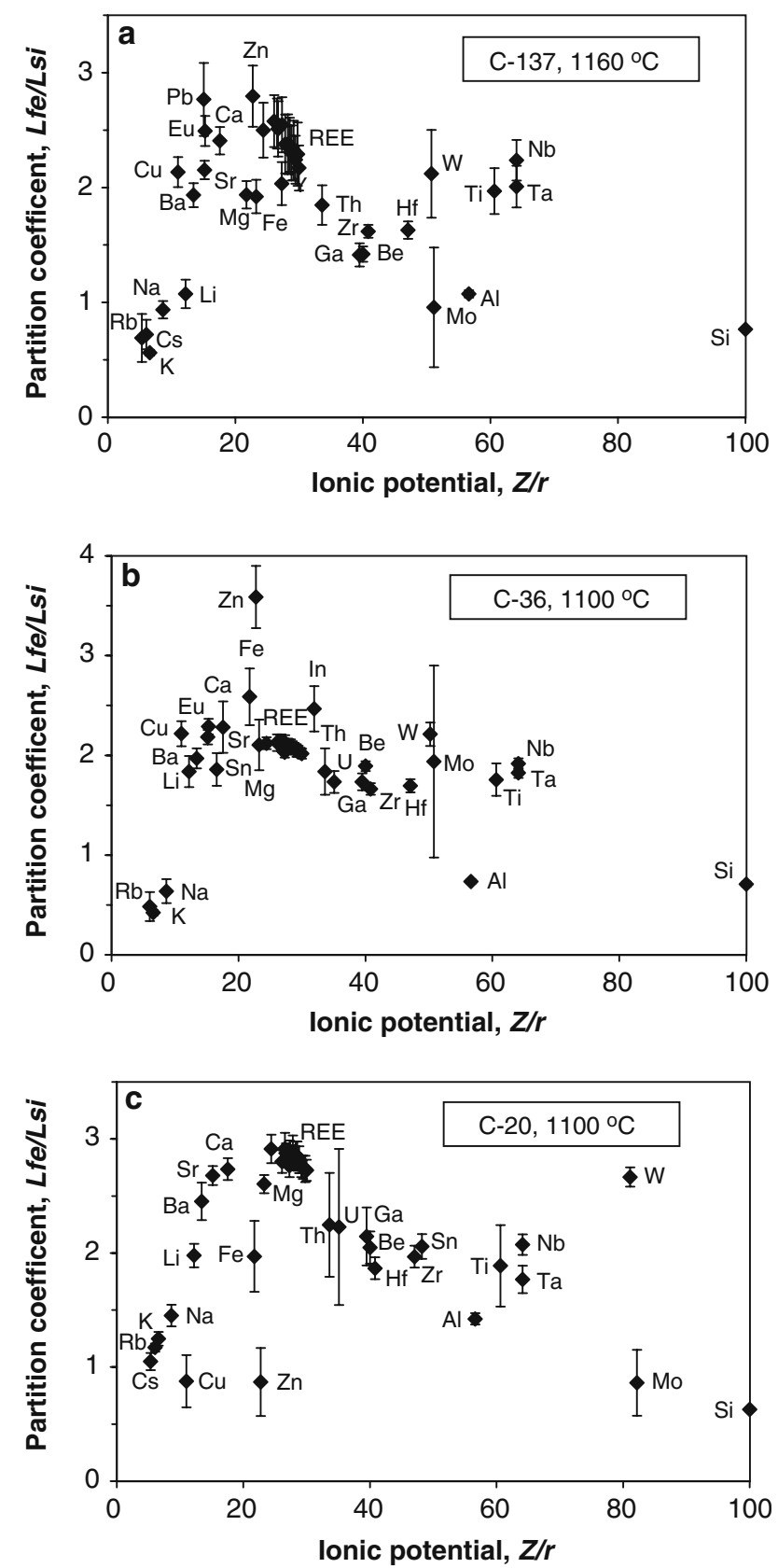

Fig. 4 Liquid-liquid Nernst partition coefficients $D$ plotted against ionic potential $\mathrm{Z} / r$ two-liquid field at temperatures above olivine and oxide liquidus generally decrease, as one would expect, with rising temperature, as the compositions of conjugate melts become closer while consolute (critical) temperature is approached and the miscibility gap closes up. Judging by the low $D$ values in the sample C40 (Table 4), the consolute temperature for the starting mixture SF- 1 is not far above $1,150^{\circ} \mathrm{C}$.

\section{Discussion}

\section{Attainment of equilibrium}

Vertical chemical gradients in the bottom $L f e$ layers (Fig. 3), diffuse streaks and intermingling of $L f e$ and Lsi instead of sharp liquid-liquid interfaces in the ferrobasaltic charges (Fig. 2b) suggest incomplete separation of the immiscible liquids, possible heterogeneity on a sub-micron scale, and are obvious signs of thermodynamic disequilibrium. The attainment of chemical equilibrium between phases is a crucial issue, which bears upon the reliability of the key liquid-liquid $D$ values in Table 5. Centrifuge separation is a new technique, which enabled us to obtain large, analysable pools of immiscible liquids, but limited run durations may have hampered chemical equilibration of the phases by convection and diffusion. In this section we examine the problem of equilibrium, drawing comparisons with other previous studies of silicate liquid immiscibility, and using thermodynamic criteria based on regression of experimental data.

\section{Oxygen fugacity}

Oxygen fugacity in the ferrobasaltic charges was buffered by the dissolution reaction of metal iron (the inner container) in silicate melts:

$\mathrm{Fe}($ metal $)+\frac{1}{2} \mathrm{O}_{2}($ gas $)=\mathrm{FeO}($ liquid $)$

Notably, this reaction of liquid(s) with metal iron container buffers not only oxygen fugacity, but also the activity of $\mathrm{FeO}$ component. Ariskin et al. (1997) calibrated the reaction using a set of 396 one-atmosphere melting experiments, in which natural or synthetic silicate liquids had been equilibrated with pure metal iron. They processed the data by least-squares fitting and presented as an expression

$\log X_{\mathrm{FeO}}^{L}=k \log f \mathrm{O}_{2}+\frac{h}{T}+\Sigma d_{j} X_{j}^{L}$ 
where $X_{\mathrm{FeO}}^{L}$ is the molar percent concentration of the ferrous $\mathrm{Fe}$ in the melt, $X_{j}^{L}$ are molar percent concentrations of seven other major oxides $\left(\mathrm{SiO}_{2}, \mathrm{TiO}_{2}\right.$, $\mathrm{Al}_{2} \mathrm{O}_{3}, \mathrm{MgO}, \mathrm{CaO}, \mathrm{Na}_{2} \mathrm{O}$ and $\mathrm{K}_{2} \mathrm{O}$ ), $T$ is absolute temperature, and $k, h$ and $d_{j}$ are regression parameters (Ariskin et al. 1997). Using this expression and liquid compositions in Table 4, we calculated $\log f \mathrm{O}_{2}$ values for the conjugate $L f e$ and $L s i$. Because the proportion of the ferric $\mathrm{Fe}$ in equilibrium with metal $\mathrm{Fe}$ is low, we assumed $X_{\mathrm{FeO}}^{L}$ to be equal to $\mathrm{FeO}$ total. If the regression equation accounts for the compositional effects well, and the equilibrium was reached, the pairs of immiscible liquids from the same run should give the same, within the analytical and statistical uncertainty, $\log f \mathrm{O}_{2}$ values close to those of the $\mathrm{Fe}-\mathrm{FeO}$ buffer. Thus, the $\mathrm{fO}_{2}$ calculation can be used as one test of chemical equilibrium.

The results are presented in Table 6. All the calculated $\log f \mathrm{O}_{2}$ values are approximately $0.5-1 \log$-units lower than those of the $\mathrm{Fe}-\mathrm{FeO}$ buffer, exactly as expected as the $\mathrm{FeO}$ activities in the liquids (and also the oxide solid solutions, when they are present) are less than 1 . The fugacities obtained for the Si-rich liquids Lsi are however systematically lower than those for the conjugate Fe-rich $L f e$ by $0.36-0.76 \log$-units. Compared to the estimated accuracy of the calculated log$f \mathrm{O}_{2}$ values $( \pm 0.1$ at $1 \sigma$ level, Ariskin et al. 1997), the difference appears to be significant, and may indicate chemical disequilibrium. It should be noted though, that the equation was calibrated against experiments at higher temperatures and more basic compositions, and may not work well for rhyolitic liquids. Our further calculations showed that not only our compositions, but all the previously published analyses of $L s i$ and $L f e$ pairs kept in Fe containers (Longhi 1990; Roedder and
Weiblen 1970; Watson 1976) gave systematically lower $\log f \mathrm{O}_{2}$ values for $L s i$, and the $L s i-L f e$ difference in the calculated $\log f \mathrm{O}_{2}$ values often exceeded 1 log-unit. One may thus conclude that either the extrapolation of the equation to lower temperatures and more silicic compositions does not work well, or rhyolitic liquids never equilibrate with metal iron and conjugate $L f e$ at experimentally realistic run durations. In any case, our liquid compositions seem to pass the equilibration test reasonably well, no worse than the previously published results.

\section{$\mathrm{Fe}-\mathrm{Mg}$ distribution between olivine and the immiscible liquids}

In olivine-saturated experiments chemical equilibrium is traditionally checked by compliance of $\mathrm{Fe}-\mathrm{Mg}$ distribution between olivine and melt with the experimentally calibrated equilibrium constant $K_{\mathrm{D}}$. Roeder and Emslie (1970) showed that the distribution constant $K_{\mathrm{D}}$ calculated as

$K_{\mathrm{D}}=\frac{X_{\mathrm{Fe}}^{\mathrm{ol}} / X_{\mathrm{Mg}}^{\mathrm{ol}}}{X_{\mathrm{Fe}}^{\mathrm{L}} / X_{\mathrm{Mg}}^{\mathrm{L}}}$

in melt compositions similar to natural tholeiites does not vary much with temperature and is close to the value of $0.3 \pm 0.03$. The $K_{\mathrm{D}}$ values in our olivinesaturated runs calculated from the data in Tables 3 and 4 are much greater than the classical basaltic value: $0.46-0.5$ for the olivine $-L f e$ distribution, and $0.55-0.58$ for the olivine-Lsi distribution (Table 6). The experimental immiscible liquids are however compositionally far from common tholeiitic basalts. Two recent studies, which revisited the $K_{\mathrm{D}}$ calibration, reported a strong

Table 6 Oxygen fugacity calculated for the immiscible liquids $L f e$ and Lsi using the equation by Ariskin et al. (1997), and the experimental $K_{\mathrm{D}}$ values of the olivine-melt equilibria compared to the models by Kilinc and Gerke (2003) and Toplis (2005)

\begin{tabular}{|c|c|c|c|c|c|c|c|}
\hline \multirow[t]{2}{*}{ Sample } & \multirow[t]{2}{*}{ Liquid } & \multirow[t]{2}{*}{ Equilibrium crystals } & \multirow[t]{2}{*}{$T\left({ }^{\circ} \mathrm{C}\right)$} & \multirow[t]{2}{*}{ Calculated $\log \mathrm{fO}_{2}$} & \multicolumn{3}{|c|}{$K_{\mathrm{D}}$ olivine-melt } \\
\hline & & & & & Measured & Kilinc and Gerke (2003) & Toplis (2005) \\
\hline C-137 & Lfe & $\operatorname{tr}$ & 1,160 & -13.4 & & & \\
\hline C-137 & Lsi & $\operatorname{tr}$ & 1,160 & -13.9 & & & \\
\hline C-40 & $L f e$ & $\operatorname{tr}$ & 1,150 & -13.2 & & & \\
\hline C-40 & Lsi & $\operatorname{tr}$ & 1,150 & -13.6 & & & \\
\hline C-39 & $L f e$ & $\operatorname{tr}$ & 1,125 & -13.4 & & & \\
\hline C-39 & Lsi & $\operatorname{tr}$ & 1,125 & -13.8 & & & \\
\hline $\mathrm{C}-36$ & $L f e$ & $\mathrm{ol}+\mathrm{Fe}-\mathrm{Ti}+\mathrm{tr}$ & 1,100 & -13.8 & 0.47 & 0.29 & 0.45 \\
\hline C-36 & Lsi & $\mathrm{ol}+\mathrm{Fe}-\mathrm{Ti}+\operatorname{tr}$ & 1,100 & -14.5 & 0.58 & 0.63 & 0.39 \\
\hline $\mathrm{C}-37$ & Lfe & $\mathrm{ol}+\mathrm{Fe}-\mathrm{Ti}+\mathrm{tr}$ & 1,075 & -14.2 & 0.47 & 0.30 & 0.45 \\
\hline $\mathrm{C}-37$ & Lsi & $\mathrm{ol}+\mathrm{Fe}-\mathrm{Ti}+\mathrm{tr}$ & 1,075 & -14.8 & 0.56 & 0.60 & 0.39 \\
\hline C-38 & Lfe & $\mathrm{ol}+\mathrm{Fe}-\mathrm{Ti}+\operatorname{tr}$ & 1,050 & -14.6 & 0.52 & 0.31 & 0.46 \\
\hline $\mathrm{C}-38$ & Lsi & $\mathrm{ol}+\mathrm{Fe}-\mathrm{Ti}+\mathrm{tr}$ & 1,050 & -15.2 & 0.57 & 0.58 & 0.38 \\
\hline
\end{tabular}

Abbreviations for the liquid and crystal phases the same as in Table 2 
compositional dependence of the constant. Kilinc and Gerke (2003) showed that $K_{\mathrm{D}}$ values could be as low as 0.18 in silica-undersaturated alkali basalt compositions, and up to 0.68 in silica-rich andesitic-rhyolitic melts. The $K_{\mathrm{D}}$ variations in the experimental data set used by Toplis (2005) ranged from 0.17 to 0.45 . It follows that silica activity and alkali content in the melt strongly affect the $K_{\mathrm{D}}$. All our ferrobasaltic run products were saturated in pure silica (tridymite), and consequently silica activity in the immiscible liquids was fixed at 1 . The elevated $K_{\mathrm{D}}$ values may thus reflect the very high silica activity in the liquids.

We also used regression equations proposed by Toplis (2005) and Kilinc and Gerke (2003), which calculated $K_{\mathrm{D}}$ 's from melt composition and experimental conditions. The results are presented in Table 6 , and they are mixed. On one hand, the equations by Toplis (2005) reproduce our olivine- $L f e K_{\mathrm{D}}$ values very well, but they do not give the same excellent results for Lsi. On the other hand, the compositional regression by Kilinc and Gerke (2003) is consistent with our experimental values for $L s i$, but does not work well for the $L f e$ compositions. One should also keep in mind that the $K_{\mathrm{D}}$ estimations have large error margins because of large analytical uncertainties for $\mathrm{MgO}$ at low concentrations, especially in Lsi. All in all, it may be concluded that our liquid compositions in ferrobasaltic runs pass the olivine $K_{\mathrm{D}}$ test satisfactory, and further improvements are probably needed in the regression equations to better account for the compositional effects.

Previous reports of olivine composition in equilibrium with the immiscible liquids are limited, to our knowledge, to a single analysis of olivine $\mathrm{Fo}_{5}$ at $1,045^{\circ} \mathrm{C}$ reported by Roedder and Weiblen (1970), which gives $K_{\mathrm{D}}$ value of 0.87 for the Fe-rich liquid and 0.54 for the silica-rich liquid. The value 0.87 is way too high, but the value for the silica-rich liquid is in good agreement with our study.

\section{Effects of incomplete phase separation}

Blurred Lfe-Lsi interfaces (Fig. 2b), and vertical chemical gradients in ferrobasaltic samples (Fig. 3) imply that the quench glasses may be heterogeneous at sub-micron scale, and the heterogeneity may have arisen from incomplete separation of fine emulsions in the liquids before quench. Incomplete phase separation would primarily affect the absolute $D$ values, but should have much smaller effect upon the relationship between the $D$ values of individual elements in the same sample. If we are sampling incompletely separated emulsions, $D$ values will be converging to 1 , but all the elements will be affected proportionately, and inter-elemental comparisons will be still valid. Because of the possibility of incomplete phase separation and mutual contamination of the liquids the absolute $D$ values in Table 4 should be treated with caution and considered as minimal estimates. The contamination will not affect however the general patterns of elemental plots, like those presented in Fig. 4.

\section{Effects of variable diffusion rates}

If liquid-liquid chemical equilibration is controlled by diffusion, and run durations were not long enough to achieve complete equilibration, one may expect a situation when equilibrium is reacted for elements with rapidly diffusing cations (e.g., Li and other alkalis), and not reached for slowly diffusing components (e.g., HFSE). In contrast to incomplete phase separation, variable diffusion rates will affect not only absolute $D$ values, but also elemental ratios of slowly and rapidly diffusing elements. Although such a possibility cannot be completely ruled out in our runs, comparisons with previous kinetic studies (Martin and Kusiro 1991) and partitioning data obtained in experiments at longer durations (Watson 1976; Ryerson and Hess 1978; Vicenzi et al. 1994; Schmidt et al. 2006) suggest that the diffusion effects are likely to be minor at the timescale of our experiments. The effects of variable cooling rates upon phase separation and liquid-liquid element partitioning have been studied by Martin and Kushiro (1991). Their study demonstrated a fast kinetics of liquid-liquid chemical equilibration and small variations of the $D$ values in response to variable cooling rates. In our experiments, phase separation and chemical equilibration should be enhanced in the sample C-137 where the proportion of the viscous Lsi liquid is very low (Fig. 2b). It is notable that the $D$ values in C-137, although in general more contrasting than those in the C-40 run at similar $T$, show the same overall pattern of element partitioning. Finally, within certain limits imposed by variations in melt composition, pressure and temperature, our $D$ values are in good agreement with previous estimations, and this is a further indication of the validity of our data. Generally, a good agreement with recent partitioning results by Schmidt et al. (2006) is most encouraging in this regard. Schmidt et al. (2006) also used centrifuge phase separation, but their samples were pre-equilibrated for $12 \mathrm{~h}$ at static conditions, and $P$ and $T$ of interest. The overall span of the absolute $D$ values by Schmidt et al. (2006) appear to be greater, but the pattern of the $D-Z / r$ plot is very similar to that presented in Fig. 4. 


\section{Relationships between partition coefficients and ionic potentials}

Before looking at individual elements, let us consider first the overall pattern of the $D$ values plotted against ionic potential $Z / r$ (Fig. 4). The plots show that with increasing $Z / r$ the $D$ values in all the compositions first increase, reach a maximum somewhere between $\mathrm{Ca}$ and La, and then decrease slowly. Highly charged cations with $Z / r$ greater than 40 show a very large scatter of $D$ values, but even in that region many elements are distributed in a similar way in all the three compositions. In fact, such general pattern of the $D-Z / r$ plots is characteristic not only for the aluminosilicate and borosilicate immiscible liquids, but other cases of immiscibility including silicate melts and various molten salts (Veksler 2004; Veksler et al. 2005). Let us now proceed to specific chemical and structural groups of elements.

Alkalis and alkaline earths

Alkalis from $\mathrm{K}$ to $\mathrm{Li}$ and alkaline earths from $\mathrm{Ba}$ to Ca show gradual increase in the liquid-liquid $D$ values consistent with the increasing $Z / r$ of the cations, and in good agreement with broadening miscibility gaps in the oxide-silica binaries (Hess 1995; Hudon and Baker 2002a). In the binaries, the tendency to liquid immiscibility increases in the order $\mathrm{K}<\mathrm{Na}<\mathrm{Li}<\mathrm{Ba}<\mathrm{Sr}<\mathrm{Ca}<\mathrm{Mg}$ as do, in general, the liquid-liquid $D$ values (Table 5; Fig. 4). In our experiments $D_{\mathrm{Mg}}$ is however systematically lower than $D_{\mathrm{Ca}}$, but this drop can be explained by the amphoteric properties of $\mathrm{Mg}^{2+}$ cation (Hudon and Baker 2002a; see also Schmidt et al. 2006). The tendency develops even further as we move to $\mathrm{Be}^{2+}$, which is more amphoteric than $\mathrm{Mg}^{2+}$, and accordingly, has a lower $D$ value.

Oxide-silica binaries of $\mathrm{Rb}$ and $\mathrm{Cs}$ show no signs of liquid immiscibility, and in the ferrobasaltic compositions the elements concentrated in Lsi. In our ferrobasaltic samples $D$ values of $\mathrm{Rb}$ and $\mathrm{Cs}$ are same as $D_{\mathrm{K}}$ within the analytical uncertainty. Other studies (Watson 1976; Vicenzi et al. 1994; Schmidt et al. 2006) demonstrated a systematic and significant variation in compliance with the general $D-Z / r$ trend: $D_{\mathrm{Cs}}<D_{\mathrm{Rb}}$ $<D_{\mathrm{K}}$. The trend is also revealed in our borosilicate sample C-20 (Fig. 4c; Table 5).

In Fig. 5 the $D$ values of the univalent alkalis and some divalent cations are plotted against $r$ and fitted with parabolic curves. Such plots are similar to the Onuma diagrams, which are broadly used for plotting crystal-liquid partition coefficients (e.g., Blundy and
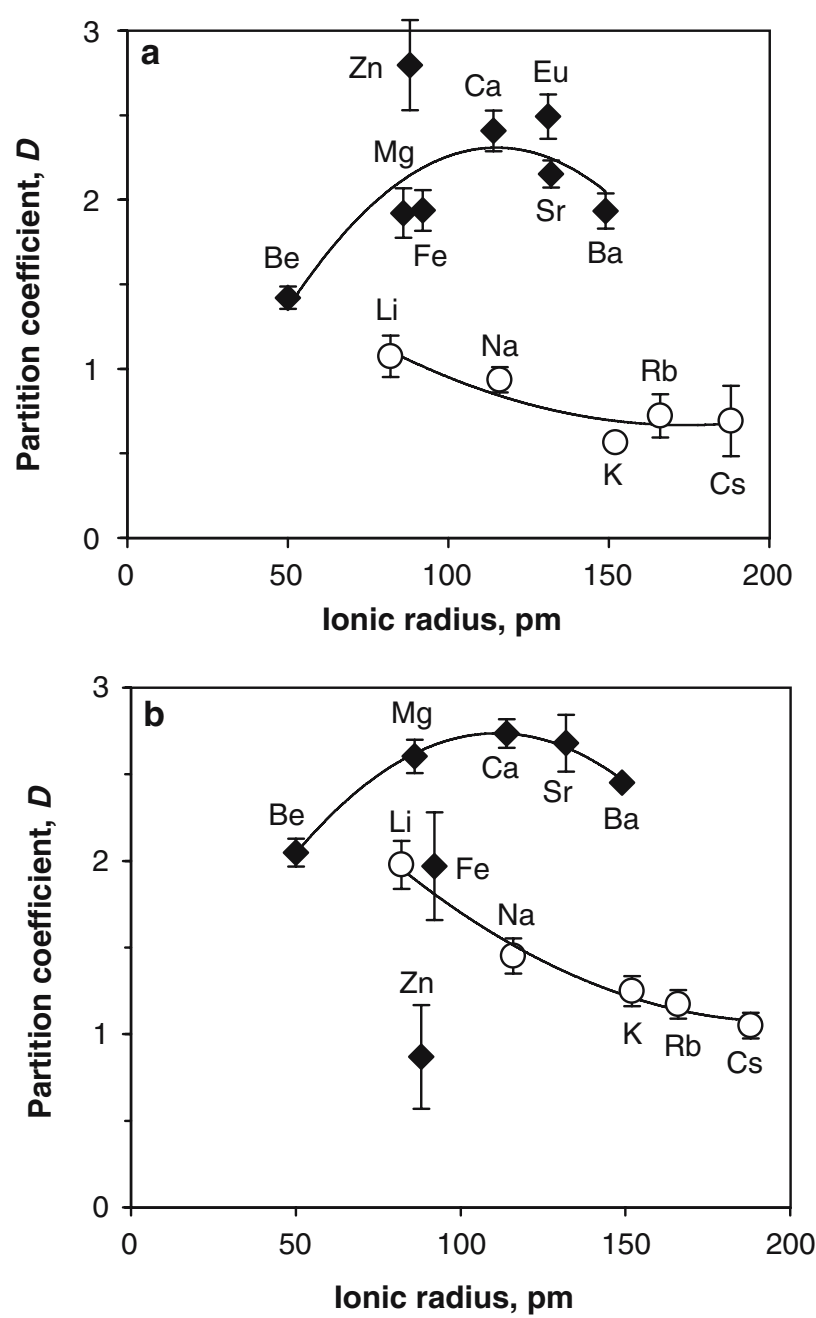

Fig. 5 Partition coefficients plotted against ionic radii. a Ferrobasaltic sample C-137. b Borosilicate sample C-20

Wood 1994). The parabolic fits are tight and convex for the divalent cations, and slightly concave for the alkalis. The implications of Fig. 5 for crystal-melt partitioning are discussed in one of the following sections in more detail.

Transition elements $\mathrm{Cu}, \mathrm{Fe}$, and $\mathrm{Zn}$

In the ferrobasaltic compositions, $D$ values of these elements usually plot above the main trend (Figs. 4, 5). Slightly anomalous $D_{\mathrm{Fe}}$ values can well be explained in light of the classification proposed by Hudon and Baker (2002a, b), as $\mathrm{Fe}^{2+}$ belongs to the VCFSE (variable field strength stabilisation energy) cations. Such an explanation is not valid, though, for $\mathrm{Cu}^{+}$and $\mathrm{Zn}^{2+}$, which in the ferrobasaltic composition also show significantly higher $D$ values than the homovalent cations with a similar $Z / r$. In fact, $\mathrm{Zn}$ in our ferrobasaltic samples shows the highest $D$ value among all the 
studied elements. In the binary systems, $\mathrm{Zn}^{2+}$ is classified as an amphoteric cation (Hudon and Baker 2002a), and that implies, if anything, anomalously low $D_{\mathrm{Zn}}$ values. Systematically lower $D_{\mathrm{Zn}}$ values were demonstrated, in accordance with the theoretical predictions, in experiments by Schmidt et al. (2006). No comparisons can be done for $\mathrm{Cu}$, because this element has never been included, to the best of our knowledge, in liquid-liquid partitioning studies before.

One possible explanation for the unusual behaviour of $\mathrm{Cu}$ and $\mathrm{Zn}$ in our runs might be that in the reduced conditions set by the $\mathrm{Fe}-\mathrm{FeO}$ buffer $\mathrm{Cu}$ and $\mathrm{Zn}$ are partly reduced to metal (see, for example, O'Neil and Pownceby (1993) for the data on the $\mathrm{Cu}-\mathrm{Cu}_{2} \mathrm{O}$ equilibrium), and form tiny alloy droplets sinking down and contaminating the Lfe layer. However, the experiments by Schmidt et al. (2006), which demonstrated low $D_{\mathrm{Zn}}$ values, were also at similarly reducing conditions set by the Mo- $\mathrm{MoO}_{2}$ buffer. Thus, it seems that no simple explanation can be offered for $\mathrm{Zn}$ and $\mathrm{Cu}$ at the moment, and the matter should be resolved in future experiments carried out at more oxidising conditions. Notably, some studies of natural immiscible glasses report high $\mathrm{ZnO}$ contents, at about $0.2 \mathrm{wt} . \%$ in Fe-rich globules (Naumov et al. 1993; Hurai et al. 1998), but the globules are too high in total Fe to be directly comparable with our glass compositions.

In the borosilicate composition, which was run in air (sample C-20), all the transition elements have, on the contrary, anomalously low $D$ values. The reason for such partitioning is again not clear, but apparently the $D$ values result from chemical interactions of $\mathrm{Cu}^{2+}$, $\mathrm{Zn}^{2+}$ and $\mathrm{Fe}$ cations with borate and borosilicate species. For instance, the anomalously low $D$ values of the transition elements may indicate that these elements do not bond well with the trigonal $\left(\mathrm{BO}_{3}\right)^{3-}$ anions, which are likely to be more abundant in the $L b$ immiscible liquid than in the Lsi according to the previous studies of speciation of borosilicate immiscible glasses by Raman spectroscopy (Veksler et al. 2002).

\section{Rare earth elements}

With the exception of $\mathrm{Eu}^{2+}, \mathrm{REE}$ form trivalent cations with $r$ gradually decreasing from $123 \mathrm{pm}\left(\mathrm{La}^{3+}\right)$ to $100.1 \mathrm{pm}\left(\mathrm{Lu}^{3+}\right)$. The $D$ values of the REE trivalent cations slightly decrease with the increasing atomic number, as the heavier REE become increasingly amphoteric (Hudon and Baker 2002a). Europium has two oxidation states: $2+$ and $3+$, and $\mathrm{Eu}^{2+}$ has $r$ and $Z / r$ values close to those of $\mathrm{Sr}^{2+}$ (Table 5). In the reduced ferrobasaltic compositions, $\mathrm{Eu}$ is predominantly in the divalent form, and accordingly $D_{\mathrm{Eu}}$ in them is close to $D_{\mathrm{Sr}}$. In contrast, borosilicate composition was run at oxidised conditions, in which $\mathrm{Eu}$ should form $\mathrm{Eu}^{3+}$, and $D_{\mathrm{Eu}}$ accordingly plot in-between $D_{\mathrm{Sm}}$ and $D_{\mathrm{Gd}}$ (Fig. 4c). In general, REE are among the most contrastingly distributed elements, and they strongly enrich the depolymerised $L f e$ and $L b$ liquids. Other authors (Watson 1976; Ryerson and Hess 1978; Vicenzi 1994; Schmidt et al. 2006) usually reported higher absolute $D_{\text {REE }}$ values, up to about 5 or 10 , with $D_{\text {REE }}$ higher than $D_{\mathrm{Fe}}$ (like in our sample C-137).

\section{High field strength elements}

In the group of high field strength elements (HFSE) we include $\mathrm{Ti}, \mathrm{Zr}, \mathrm{Hf}, \mathrm{Nb}$, Ta, Mo and $\mathrm{W}$, which form relatively small cations with the nominal charges from $4+$ to $6+$. Most of the elements have multiple oxidation states, and thus the observed $D$ values listed in Table 5 may in fact represent some effective mixtures of several ions with different $Z$. The situation is particularly complex for Mo and $\mathrm{W}$, which are likely to form 4+ cations in reduced ferrobasaltic samples, and $6+$ cations in the oxidised borosilicate sample C-20 (see Holzheid et al. 1994; Ertel et al. 1996; O'Neil and Eggins 2002 for the data on Mo and W oxidation states in silicate melts). The exact proportion of the $4+$ and $6+$ cations in our samples are not known. In Table 5 and Fig. 5 we simply assumed all Mo and $\mathrm{W}$ as $4+$ in ferrobasltic samples and $6+$ in the borosilicate sample. The choice of the $r$ values is also arbitrary because in silicate crystals and melts the cations can have more than one coordination number.

The scatter of the $D$ values in the high field strength part of the plots in Fig. 4 is in any case so large that it defies an easy structural interpretation. With the exception of Mo, the $D$ values of the HFSE seem to form a sequence: $D_{\mathrm{Zr}}=D_{\mathrm{Hf}}<D_{\mathrm{Ti}}=D_{\mathrm{Ta}}<D_{\mathrm{Nb}}<$ $D_{\mathrm{W}}$, with a rough positive correlation with $Z$, and also $Z / r$. As one moves from the $4+$ cations to $5+$ and $6+$, the chemical properties of the oxides change from amphoteric to increasingly acidic, and the tendency of the cations to form oxyanions, such as $\left(\mathrm{WO}_{4}\right)^{2-}$, also increases. The growing $D$ values may reflect a growing tendency of the oxyanions to bond with typical network-modifying cations, such as alkalis and alkaline earths, rather than insert themselves into polymerised aluminosilicate or borosilicate networks. The interactions with the cations in the depolymerised $L f e$ and $L b$ seem to be more important for the partitioning behaviour of the HFSE than their compatibility with the polymerised network structure of Lsi. Comparisons with the oxide-silica binaries and ternaries are 
instructive in this respect. For instance, Stemprok (1974) reported no liquid immiscibility along the $\mathrm{WO}_{3}-\mathrm{SiO}_{2}$ and $\mathrm{MoO}_{3}-\mathrm{SiO}_{2}$ border joins, but drew broad ternary miscibility gaps in the $\mathrm{Na}_{2} \mathrm{O}-\mathrm{WO}_{3}$ $\mathrm{SiO}_{2}$ and $\mathrm{Na}_{2} \mathrm{O}-\mathrm{MoO}_{3}-\mathrm{SiO}_{2}$ systems at $1,200^{\circ} \mathrm{C}$. An interesting analogy is also provided by phosphorus. Apparently, there is no liquid immiscibility in the $\mathrm{P}_{2} \mathrm{O}_{5}-\mathrm{SiO}_{2}$ binary (Tien and Hummel 1962), but in ferrobasaltic systems $\mathrm{P}_{2} \mathrm{O}_{5}$ strongly enhances silicate liquid immiscibility, strongly concentrates on the Fe-rich liquid, and greatly increases the $D$ values of network-modifying cations, such as alkaline earths and REE (Watson 1976; Ryerson and Hess 1978). Because of those effects, we deliberately excluded $\mathrm{P}$ from our starting compositions.

The decoupling of the $\mathrm{Zr}-\mathrm{Hf}, \mathrm{Nb}-\mathrm{Ta}$ and $\mathrm{W}-\mathrm{Mo}$ pairs is a notable feature of liquid-liquid equilibria in salt melt-silicate melt element partitioning (Veksler et al. 1998; Veksler 2004). As a rule, Zr, Nb and W have greater affinity to depolymerised, ionic liquids than their chemical "twins", so that $D_{\mathrm{Zr}}>D_{\mathrm{Hf}}$, $D_{\mathrm{Nb}}>D_{\mathrm{Ta}}$ and $D_{\mathrm{W}}>D_{\mathrm{Mo}}$. The decoupling defies an explanation in the frame of the simple ionic model, because in any system of ionic radii, the size and $Z / r$ values of the "twins" are very close. That is probably where the simple model fails, and the explanation should be sought in more sophisticated theories of chemical bonds. For some reason, Mo and $\mathrm{W}$ show a very large scatter in ferrobsaltic samples, and the decoupling of the Mo-W, $\mathrm{Zr}-\mathrm{Hf}$ and $\mathrm{Nb}-\mathrm{Ta}$ pairs is insignificant in the $L f e-L s i$ partitioning, when standard deviations (Table 5) are taken into account.

\section{Network formers}

Within the group, which includes $\mathrm{Si}^{4+}, \mathrm{Al}^{3+}, \mathrm{Ga}^{3+}$, and $\mathrm{B}^{3+}, \mathrm{Si}^{4+}$ is a perfect network former, while $\mathrm{Al}^{3+}$ and $\mathrm{Ga}^{3+}$ are somewhat too large and consequently amphoteric, and $\mathrm{B}^{3+}$ is too small and thus fitting into trigonal and tetrahedral sites. Indium lies below $\mathrm{Al}$ and $\mathrm{Ga}$ in the periodic table, but $\mathrm{In}^{3+}$ is too large to be a network former. In our ferrobasaltic compositions, $\mathrm{In}^{3+}$ tends to plot slightly above the main trend of the $D$ values (Fig. 4), but we cannot offer any explanation for such behaviour. $\mathrm{Si}^{4+}$ and $\mathrm{Al}^{3+}$ obviously concentrate in Lsi, while $\mathrm{B}^{3+}$ in the borosilicate composition preferentially partitions to the depolymerised $L b$ (see also Veksler et al. 2002). As with the HFSE, the liquidliquid partitioning of $\mathrm{Al}^{3+}$ and $\mathrm{B}^{3+}$ appears to be strongly affected by chemical interactions with network-modifying cations, such as alkalis and alkaline earths. For instance, the partitioning of $\mathrm{Al}^{3+}$ to $L s i$ seems to be enhanced by the formation of strongly polymerised feldspathoid species, which mix well with silica networks. That is probably why $\mathrm{Al}^{3+}$ in Fig. 4a and $\mathrm{b}$ tends to plot below the main down-slope trend formed by $\mathrm{Be}^{2+}, \mathrm{Ga}^{3+}$ and $\mathrm{Si}^{4+}$. Because of the ambiguity of the proportion between the trigonal and tetrahedral $\mathrm{B}^{3+}$ and uncertainty of the effective $r$ value, $\mathrm{B}^{3+}$ is not included in the $Z / r$ systematics and not plotted in Fig. 4c.

\section{Implications to crystal-melt element partitioning}

The effects of melt composition upon crystal-melt element partitioning have been a matter of extensive discussion in recent years (e.g., Mysen 2004; O'Neil and Eggins 2002; Prowatke and Klemme 2005; Schmidt et al. 2006). Watson (1976) and Ryerson and Hess (1978) were probably the first to propose that studies of immiscibility and two-liquid element distribution can help to better understand and quantify these effects, and Schmidt et al. (2006) developed the approach much further both experimentally and in their theoretical model. The liquid-liquid partitioning results presented here (Table 5; Fig. 4) imply that the melt composition effects should be the strongest for the most strongly fractionated elements. Transition metals are likely to be decoupled from other cations of a similar $Z / r$, as evidenced, for example, by the already discussed strong compositional dependence of the olivine-melt $K_{\mathrm{D}}$ (see also Kushiro and Mysen 2002). Strong and very complex effects are likely for the HFSE, and their crystal-melt partitioning may depend not only on degree of polymerisation of the silicate melt network, but also on the type of predominant network-modifying cations.

It is also important to note that the melt effects upon cations are not a linear function of $Z / r$. Non-linear patterns have been established in binary systems (Hudon and Baker 2002a, b), and are confirmed in the complex multicomponent compositions presented here. Despite the absence of lattice strain from liquids, the liquid-liquid $D$ values of di- and trivalent network formers and amphoteric cations appear to form convex parabolic fits (see some examples in Fig. 5), similar to those calculated for crystal-liquid element partitioning using the lattice strain model developed by Blundy and Wood (1994). The lattice strain model, which basically ignores the melt effects, may work so well partly because of the similarity between the "parabolic" distribution of cations between different species in the melt, and between melt and crystal. The similarity does not however hold for the highly charged HFSE. In our runs, $\mathrm{W}$ and Mo having almost identical $Z$ and $r$ are 
strongly fractionated, but $D_{\mathrm{Nb}} / D_{\mathrm{Ta}}$ does not exceed 1.1 in ferrobasaltic compositions, and 1.17 in the borosilicate composition, and is within the limits of analytical uncertainty. In the study by Vicenzi et al. (1994), the $\mathrm{Nb}-\mathrm{Ta}$ fractionation between the iron-rich and silicaterich immiscible liquids was however significant, with $D_{\mathrm{Nb}} / D_{\mathrm{Ta}}$ values up to 1.35 . The significant liquid-liquid fractionation proves that the difference in the crystalliquid $D_{\mathrm{Nb}}$ and $D_{\mathrm{Ta}}$ values (e.g., Horng and Hess 2000; Prowatke and Klemme 2005) cannot be due to effects of crystal lattices only, and the speciation and local environments of $\mathrm{Nb}^{5+}$ and $\mathrm{Ta}^{5+}$ cations in liquid phase should play an important role.

\section{Silicate liquid immiscibility in basaltic magmas}

Recent findings of the conjugate Fe-rich and Si-rich melt inclusions in evolved gabbroic rocks from the Upper Zone of the Skaergaard intrusion, East Greenland (Jakobsen et al. 2005) confirm the viability of silicate liquid immiscibility as a petrogenetic process. The melt inclusion study proved that silicate liquid immiscibility proposed for Skaergaard (McBirney 1975; McBirney and Nakamura 1974) had taken place indeed, and because the Skaergaard intrusion has been considered for decades as the classical example of a tholeiitic magma chamber, liquid immiscibility may be not unique to Skaergaard but could have played a role, as it was proposed before, in other mafic intrusions such as the Stillwater complex (Loferski and Arculus 1993) and the Pleasant Bay intrusion (Wiebe 1997). In a series of ongoing experiments, we are now revisiting the extent and petrogenetic significance of silicate liquid immiscibility in natural basaltic magma. A detailed account of the results will be published elsewhere, and only some general considerations are presented below.

Conditions for silicate liquid immiscibility in basaltic magma

The timing of silicate liquid immiscibility is crucial, and the earlier immiscibility starts, the greater its potential geochemical and petrogenetic role can be. Previous experimental studies, which used tholeiitic starting compositions (Philpotts 1979; Dixon and Rutherford 1979; McBirney and Nakamura 1974; McBirney and Naslund 1990), usually reported the onset of silicate liquid immiscibility at temperatures around 1,010 $1,040^{\circ} \mathrm{C}$, and only $5-10 \%$ of residual liquid. The evolved Upper Zone of the Skaergaard intrusion is believed to form at $1,000-1,085^{\circ} \mathrm{C}$ (e.g., McBirney and Naslund 1990; Ariskin 2002) and the degree of crystallisation 0.8 (Nielsen 2004). The occurrence of the immiscible liquids in melt inclusions from the Upper Zone (Jakobsen et al. 2005) is thus in good agreement with the experiments. This study documents liquid immiscibility at temperature as high as $1,160^{\circ} \mathrm{C}$ (sample C-137) and $\mathrm{FeO}$ concentration in Lfe of around $21 \mathrm{wt} . \%$, well achievable during crystallisation of the Skaergaard magma (Toplis and Carroll 1995). It should be noted however that the bulk composition SF-2 used in the experiment C-137 is not a perfect analogue of the Skaergaard magma, and the immiscible liquids in $\mathrm{C}-137$ precipitate tridymite, but not olivine, plagioclase, pyroxenes and $\mathrm{Fe}-\mathrm{Ti}$ oxides as should be in Skaergaard. Crystallisation experiments with the Skaergaard bulk composition (Toplis and Carroll 1995) did not report liquid immiscibility. Nevertheless, the occurrence of high-temperature unmixing in the sample C-137 demands that the compositional and temperature extent of liquid immiscibility in natural ferrobasaltic liquids should be revisited.

Oxygen fugacity in our experiments in iron containers (Table 6) was too low compared to the conditions expected in vast majority of terrestrial tholeiitic magmas. Previous experimental studies (Naslund 1983; Philpotts 1979; Vicenzi et al. 1994) have shown however that more oxidised conditions favour liquid immiscibility, broaden the miscibility gaps, and increase the liquid-liquid $D$ values. Thus, it is not obvious, which of the two opposing factors-increased stability of magnetite, which prevents strong $\mathrm{Fe}$ enrichment in melt (Toplis and Carroll 1995), or enhanced liquid immiscibility-would prevail at the evolved stages of crystallisation in natural ferrobasaltic magmas of the Skaergaard type.

The ferrobasalt-rhyolite silicate liquid immiscibility appears to be very sensitive to subtle changes in melt composition, and minor components, such as $\mathrm{P}_{2} \mathrm{O}_{5}$, $\mathrm{TiO}_{2}, \mathrm{~S}$ or $\mathrm{CO}_{2}$ may determine the onset of immiscibility. The effects of volatile components may prove to be important in future experiments. In volatile-free compositions, pressure as such does not seem however to be an important factor. For instance, experiments at pressures up to $0.7 \mathrm{GPa}$ did not show significant effects on liquid immiscibility in the model $\mathrm{KAlSi}_{2} \mathrm{O}_{6}-\mathrm{Fe}_{2} \mathrm{SiO}_{4}-\mathrm{SiO}_{2}$ system (Schmidt et al. 2006).

\section{Geochemical effects of silicate liquid immiscibility}

Silicate liquid immiscibility should impose distinct geochemical imprints upon conjugate liquids, and the geochemical traces of the process may be retained in lavas and crystallised igneous rocks. Silica-rich immiscible liquids $L s i$ are similar to natural rhyolites, dacited 
and granites, and it would be not easy to distinguish them from the silicic products of fractional crystallisation of basaltic magmas. Silicic rocks produced by immiscibility should be very depleted in all incompatible trace elements except $\mathrm{Rb}$ and $\mathrm{Cs}$, and the strongest depletion is expected for light REE and HFSE. Elevated $\mathrm{Ba} / \mathrm{La}$ values, or anomalously high $\mathrm{Ta} / \mathrm{Nb}$ may be good indicators of liquid immiscibility in silicic rocks. Dixon and Rutherford (1979) proposed that silicic rocks produced by liquid immiscibility should also show high K/Ba, K/P and K/REE values. Much depends however on the effectiveness of separation of Fe-rich liquid from the pools of viscous silicic immiscible melt. The separation is difficult to achieve in centrifuge experiments, and good separation may prove to be rare in natural magmas. Any remnants of the iron-rich liquid in the silicic counterpart will obscure the geochemical indicators and the origin of the rock by immiscibility.

It has been pointed out in many previous works that contrary to the Si-rich liquid, the compositions of Fe-rich immiscible melts do not resemble any known igneous rocks, except exotic nelsonites or rare lava flows, such as the enigmatic Fe-rich lavas at the El Laco volcano, Chile (Naslund et al. 2003). This should not be considered however as a proof of rareness or insignificance of silicate liquid immiscibility in natural magmas. Dense Fe-rich liquids are not likely to erupt. Therefore, they would stay behind in magma chambers, or migrate downward in magmatic plumbing systems, and there may mix with new portions of hot, primitive mantle magmas. High $\mathrm{FeO}$ content and $\mathrm{CaO} / \mathrm{Al}_{2} \mathrm{O}_{3}$ values, strong enrichment in $\mathrm{P}, \mathrm{Ti}, \mathrm{REE}$ and HFSE are the geochemical hallmarks of the Fe-rich immiscible liquids. The liquids may also have anomalous, nonchondritic $\mathrm{Nb}$ / Ta values, and high $\mathrm{Zn}$ and $\mathrm{Cu}$ contents. Because of the enrichment and the extreme composition, even small additions of such liquids should alter geochemical characteristics of primitive basalts. The crystallisation-immiscibility-mixing cycles in longlasting and highly productive magmatic systems, such as mid-ocean ridges and mantle plumes, could eventually produce rare hybrid magmas enriched in the elements, which partition into the immiscible iron-rich melt. For example, it is notable that in rare and unusual ferropicrites, interpreted as products of heterogeneous plume mantle sources with iron-rich streaks (Gibson et al. 2000, 2002), high $\mathrm{FeO}$ contents correlate with elevated $\mathrm{CaO} / \mathrm{Al}_{2} \mathrm{O}_{3}$ values, enrichment in $\mathrm{P}, \mathrm{Ti}$, and a number of incompatible trace elements. Such correlation is not readily explained by the mantle melting models, but mixing of evolved, immiscible, iron-rich liquid into picritic magma could be, in our view, a viable alternative hypothesis.
Acknowledgments Dieter Rhede, Oona Appelt (GFZ Potsdam), and John Spratt (NHM London) are thanked for the help with electron microprobe analyses. Experimental work was supported by the DFG SPP 1055 grant to DBD (Di 431/23-1). IVV visits to NHM London were financed by CERCAMS, and a grant from EU SYNTHESYS programme. Comments of two anonymous reviewers helped us to improve the original version of the manuscript.

\section{References}

Ariskin AA (2002) Geochemical thermometry of layered series rocks of the Skaergaard intrusion. Petrology 10:495-518

Ariskin AA, Petaev MI, Borisov AA, Barmina GS (1997) METEOMOD: a numerical model for the calculation of melting-crystallization relationships in meteoritic igneous systems. Meteorit Planet Sci 32:123-133

Bowen NL (1928) The evolution of igneous rocks. Princeton University Press, Princeton

Blundy J, Wood BJ (1994) Prediction of crystal-melt partition coefficients from elastic moduli. Nature 372:452-454

Daly RA (1914) Igneous rocks and their origin. McGraw Hill, New York

Dingwell DB, Pichavant M, Holtz F (1996) Experimental studies of boron in granitic melts. In: Grew ES, Anowitz LM (eds) Boron. Mineralogy, Petrology and Geochemistry, Mineralogical Society of America, Rev Mineral, vol 33, pp 331-386

Dixon S, Rutherford MJ (1979) Plagiogranites as late-stage immiscible liquids in ophiolite and mid-ocean ridge suites: an experimental study. Earth Planet Sci Lett 45:45-60

Dorfman AM, Hess K-U, Dingwell DB (1996) Centrifugeassisted falling-sphere viscosimetry. Eur J Mineral 8:507-514

Ertel W, O'Neil HStC, Dingwell DB, Spettel B (1996) Solubility of tungsten in a haplobasaltic melt as a function of temperature and oxygen fugacity. Geochim Cosmochim Acta 60:1171-1180

Gibson SA (2002) Major element heterogeneity in Archean to recent mantle plume starting-heads. Earth Planet Sci Lett 95:59-74

Gibson SA, Thompson RN, Dickin AP (2000) Ferropicrites: geochemical evidence for Fe-rich streaks in upwelling mantle plumes. Earth Planet Sci Lett 174:355-374

Greig JW (1927) Immiscibility in silicate melts. Am J Sci 13:133154

Hess PC (1995) Thermodynamic mixing properties and the structure of silicate melts. In: Stebbins JF, McMillan PF, Dingwell DB (eds) Structure, dynamics and properties of silicate melts. Mineralogical Society of America, Rev in Mineral, vol 32, pp 145-190

Holzheid A, Borisov A, Palme H (1994) The effect of oxygen fugacity and temperature on solubilities of nickel, cobalt, and molybdenum in silicate melts. Geochim Cosmochim Acta 58:1975-1981

Horng W-S, Hess PC (2000) Partition coefficients of Nb and Ta between rutile and anhydrous haplogranite melts. Contrib Mineral Petrol 138:176-185

Hudon P, Baker DR (2002a) The nature of phase separation in binary oxide melts and glasses. I. Silicate systems. J NonCryst Solids 303:299-345

Hudon P, Baker DR (2002b) The nature of phase separation in binary oxide melts and glasses. III. Borate and germanate systems. J Non-Cryst Solids 303:354-371 
Hurai V, Simon K, Wiechert U, Hoefs J, Konečný P, Huraiová M, Pironon J, Lipka J (1998) Immiscible separation of metalliferous $\mathrm{Fe} / \mathrm{Ti}$-oxide melts from fractionating alkali basalt: $P-T-f \mathrm{O}_{2}$ conditions and two-liquid elemental partitioning. Contrib Mineral Petrol 133:12-29

Jakobsen JK, Veksler IV, Tegner C, Brooks CK (2005) Immiscible iron- and silica-rich melts in basalt petrogenesis documented in the Skaergaard intrusion. Geology 33:885-888

Kilinc A, Gerke T (2003) Compositional dependency of Fe- $\mathrm{Mg}$ exchange between olivine and melt. In: The Geological Society of America, 2003 Annual Meeting, Abstract with Programs GSA 35(6):181

Kushiro I, Mysen BO (2002) A possible effect of melt structure on the $\mathrm{Mg}-\mathrm{Fe}^{2+}$ partitioning between olivine and melt. Geochim Cosmochim Acta 66:2267-2272

Levin EM, Robbins CR, McMurdie HF (1964) Phase equilibria diagrams, vol 1. American Ceramic Society, Columbus

Loferski PJ, Arculus RJ (1993) Multiphase inclusions in plagioclase from anorthosites in the Stillwater Complex, Montana: implications for the origin of the anorthosites. Contrib Mineral Petrol 114:63-78

Longerich HP, Jackson SE, Gunther D (1996) Laser ablation inductively coupled plasma mass spectrometric transient signal data acquisition and analytic concentration calculation. J Anal Atom Spectrom 11:899-904

Longhi J (1990) Silicate liquid immiscibility in isothermal crystallization experiments. In: Proceedings of the 20th Lunar Planet Science conference, pp 13-24

Markl G (2001) A new type of liquid immiscibility in peralkaline nepheline syenites (lujavrites) of the Ilimaussaq complex, South Greenland. Contrib Mineral Petrol 141:458-472

Martin B, Kushiro Y (1991) Immiscibility synthesis as an indicator of cooling rates in basalts. J Volcanol Geotherm Res 45:289-310

McBirney AR (1975) Differentiation of the Skaergaard intrusion. Nature 253:691-694

McBirney AR (1989) The Skaergaard layered series: I. Structure and average compositions. J Petrol 30:363-397

McBirney AR, Nakamura Y (1974) Immiscibility in late-stage magmas of the Skaergaard intrusion. Carnegie Inst Wash Yearbook 73:348-352

McBirney AR, Naslund HR (1990) The differentiation of the Skaergaard intrusion. A discussion of Hunter and Sparks (Contrib Mineral Petrol 95:451-461) Contrib Mineral Petrol 104:235-247

Mysen BO (2004) Element partitioning between minerals and melt, melt composition, and melt structure. Chem Geol 213:1-16

Naslund HR (1983) The effect of oxygen fugacity on liquid immiscibility in iron-bearing silicate melts. Am J Sci 283:1034-1059

Naslund HR, Henriquez F, Nystrom JO, Aguirre R, Lledo H (2003) El Laco, Chile; evidence for the eruption of an immiscible Fe-O-S-P melt. The Geological Society of America, 2003 Annual Meeting, Abstract with Programs GSA 35(6):394

Naumov VB, Solovova IP, Kovalenker VA, Rusinov VL (1993) Immiscibility in acidic magmas: evidence from melt inclusions in quartz phenocrysts of ignimbrites. Eur J Mineral 5:937-941

Nielsen TFD (2004) The shape and volume of the Skaergaard intrusion, Greenland: implications for mass balance and bulk composition. J Petrol 45:507-530

O'Neil HStC, Eggins SM (2002) The effects of melt composition on trace element partitioning: an experimental investigation of the activity coefficients of $\mathrm{FeO}, \mathrm{NiO}, \mathrm{CoO}, \mathrm{MoO}_{2}$ and $\mathrm{MoO}_{3}$ in silicate melts. Chem Geol 186:151-181
O'Neil HStC, Pownceby MI (1993) Thermodynamic data from redox reactions at high temperatures. I. An experimental and theoretical assessment of the electrochemical method using stabilized zirconia electrolytes, with revised values fro the $\mathrm{Fe}-$ "FeO", $\mathrm{Co}-\mathrm{CoO}, \mathrm{Ni}-\mathrm{NiO}$ and $\mathrm{Cu}-\mathrm{Cu}_{2} \mathrm{O}$ oxygen buffers, and new data for the $\mathrm{W}-\mathrm{WO}_{2}$ buffer. Contrib Mineral Petrol 114:296-314

Pearce NJG, Perkins WT, Westgate JA, Gorton MP, Jackson SE, Neal CR, Chenery SP (1997) A compilation of new and published major and trace element data for NIST SRM 610 and NIST SRM 612 glass reference materials. J Geostand Geoanal 21:115-144

Philpotts AR (1976) Silicate liquid immiscibility: its probable extent and petrogenetic significance. Am J Sci 276:11471177

Philpotts AR (1979) Silicate liquid immiscibility in tholeiitic basalts. J Petrol 20:99-118

Philpotts AR (1982) Compositions of immiscible liquids in volcanic rocks. Contrib Mineral Petrol 80:201-218

Prowatke S, Klemme S (2005) Effect of melt composition on the partitioning of trace elements between titanite and silicate melt. Geochim Cosmochim Acta 69:695-709

Rajesh HM (2003) Outcrop-scale silicate liquid immiscibility from an akali syenites (A-type granitoid)-pyroxenite association near Puttetti, Trivandrum Block, South India. Contrib Mineral Petrol 145:612-627

Roedder E (1951) Low-temperature liquid immiscibility in the system $\mathrm{K}_{2} \mathrm{O}-\mathrm{FeO}-\mathrm{Al}_{2} \mathrm{O}_{3}-\mathrm{SiO}_{2}$. Amer Mineral 36:282-286

Roedder E (1979) Silicate liquid immiscibility in magmas. In: Yoder HS Jr (ed) The evolution of igneous rocks, Fiftieth Anniversary perspectives. Princeton University Press, Princeton, pp 15-58

Roedder E, Weiblen PW (1970) Lunar petrology of silicate melt inclusions, Apollo 11 rocks. In: Proceedings of the Apollo 11 Lunar Science Conference. Geochim Cosmochim Acta 1(Suppl 1):507-528

Roedder E, Weiblen PW (1971) Petrology of silicate melt inclusions, Apollo 11 and Apollo 12 and terrestrial equivalents. In: Proceedings of the 2nd Lunar Science Conference. Geochim Cosmochim Acta 1(Suppl 2):507-528

Roeder PL, Emslie RF (1970) Olivine-liquid equilibrium. Contrib Mineral Petrol 29:275-289

Ryerson FJ, Hess PC (1978) Implications of liquid-liquid distribution coefficients to mineral-liquid partitioning. Geochim Cosmochim Acta 42:921-932

Schmidt MW, Connolly JAD, Günther D, Bogaerts M (2006) Element partitioning - the role of melt structure and composition. Science 312:1646-1650

Scrope GP (1825) Consideration on volcanoes, the probable cause of their phenomena, the laws which determine their march, the disposition of their products and their connexion with the present state and past history of the globe; leading to the establishment of a new theory of the Earth. J Murray, London

Shannon RD (1976) Revised effective ionic radii and systematic studies of interatomic distances in halides and chalcogenides. Acta Crystallogr A 32:751-767

Shearer CK, Papike JJ, Spilde MN (2001) Trace element partitioning between immiscible lunar melts: An example from naturally occurring lunar melt inclusions. Am Mineral 86:238-241

Sørensen H, Bailey JC, Kogarko LN, Rose-Hansen J, KarupMøller S (2003) Spheroidal structures in arfedsonite lujavrite, Ilimaussaq alkaline complex, South Greenlandan example of macro-scale liquid immiscibility. Lithos 70:1-20 
Stemprok MS (1974) Geological importance of immiscibility in melts of silicate systems containing tungsten and molybdenum (in Russian). Izv Akad Nauk SSSR, Ser Geol 4:60-71

Tien TY, Hummel FA (1962) System $\mathrm{SiO}_{2}-\mathrm{P}_{2} \mathrm{O}_{5}$. J Am Ceram Soc 45:422-424

Toplis MJ (2005) The thermodynamics of iron and magnesium partitioning between olivine and liquid: criteria for assessing and predicting equilibrium in natural and experimental systems. Contrib Mineral Petrol 149:22-49

Toplis MJ, Carroll MR (1995) An experimental study of the influence of oxygen fugacity on $\mathrm{Fe}-\mathrm{Ti}$ oxide stability, phase relations, and mineral-melt equilibria in ferro-basaltic systems. J Petrol 36:1137-1171

Veksler IV (2004) Liquid immiscibility and its role at the magmatic-hydrothermal transition: a summary of experimental studies. Chem Geol 210:7-31

Veksler IV, Petibon C, Jenner G, Dorfman AM, Dingwell DB (1998) Trace element partitioning in immiscible silicate and carbonate liquid systems: an initial experimental study using a centrifuge autoclave. J Petrol 39:2095-2104
Veksler IV, Dorfman AM, Dingwell DB, Zotov N (2002) Element partitioning between immiscible borosilicate liquids: a high-temperature centrifuge study. Geochim Cosmochim Acta 66:2603-2614

Veksler IV, Dorfman AM, Kamanetsky M, Dulski P, Dingwell DB (2005) Partitioning of lanthanides and $\mathrm{Y}$ between immiscible silicate and fluoride melts, fluorite and cryolite and the origin of the lanthanide tetrad effect in igneous rocks. Geochim Cosmochim Acta 69:2847-2860

Vicenzi E, Green T, Sie S (1994) Effect of oxygen fugacity on trace-element partitioning between immiscible silicate melts at atmospheric pressure: a proton and electron microprobe study. Chem Geol 117:355-360

Watson EB (1976) Two-liquid partition coefficients: experimental data and geochemical implications. Contrib Mineral Petrol 56:119-134

Wiebe RA (1997) Fe-rich tholeiitic liquids and their cumulate products in the Pleasant Bay layered intrusion, coastal Maine. Contrib Mineral Petrol 129:255-267 